\title{
A Concise Synthesis of the Octalactins
}

Paul T. O’Sullivan, Wilm Buhr, Mary Ann M. Fuhry, Justin R. Harrison, John E. Davies, Neil Feeder, David R. Marshall, ${ }^{\dagger}$ Jonathan W. Burton* and Andrew B. Holmes*

Department of Chemistry, University of Cambridge, Lensfield Road, Cambridge, CB2 1EW, UK

abh1@cam.ac.uk,jwb1004@cam.ac.uk

A Concise Synthesis of the Octalactins

CORRESPONDING AUTHOR FOOTNOTE ${ }^{\dagger}$ Formerly at GlaxoSmithKline, Gunnels Wood Road, Stevenage, SG1 2NY, UK.

\section{Supporting Information}

${ }^{1}$ H NMR spectra were recorded on Bruker AC-200 (200 MHz), DPX-250 (250 MHz), WM-400 (400 MHz), AM-400 (400 MHz), DRX-400 and DRX-500 (500 MHz) spectrometers. Chemical shifts are quoted in ppm relative to tetramethylsilane $(\delta=0 \mathrm{ppm})$ and referenced to the solvent residual. For convenience, the following abbreviations are used; s - singlet, $\mathrm{d}$ - doublet, $\mathrm{t}$ - triplet, $\mathrm{q}$ - quartet, qn quintet, $\mathrm{m}$ - multiplet, dd - doublet of doublets etc. Coupling constants $(J)$ are given in Hz. Where useful, the FID was zero-filled $(128 \mathrm{~K})$ and sine-bell shifted (SSB = 30) prior to Fourier Transformation in order to provide baseline resolved multiplets and, as a result, easily identifiable and measurable coupling constants. Two dimensional (2D) spectra were recorded on a DRX-400 and a Bruker DRX-500 spectrometer fitted with gradient coils. Double Quantum Filtered (DQF) and magnitude COSY spectra were typically acquired with 256 slices in $F_{1}$ and 2048 points in $F_{2}$ (acquisition time approximately $20 \mathrm{~min}$ ). 1D gradient NOE spectra were acquired using standard 
Gauss selective pulses and mixing times $\left(\tau_{\mathrm{m}}\right)$ of the order of $1.2 \mathrm{~s} .{ }^{1}{ }^{13} \mathrm{C}$ NMR spectra were recorded on Bruker AC-200 (50 MHz), DPX-250 (62.5 MHz), AM-400 (100 MHz), WM-400 (100 MHz), DRX$400(400 \mathrm{MHz})$, and WM-200 (50 MHz) spectrometers in the solvent indicated and with proton decoupling. Chemical shifts are quoted relative to tetramethylsilane ( $\delta=0 \mathrm{ppm})$. The attached proton tests (APT) was used to assign signals in particular cases. Infrared spectra were recorded on a PerkinElmer 1600 FT IR spectrophotometer. The sample was prepared as a thin liquid film, a $\mathrm{KBr}$ disc or as a solution in the solvent indicated. Calibration was relative to polystyrene at $1603 \mathrm{~cm}^{-1}$. Mass Spectra were carried out at the EPSRC Mass Spectrometry Service Centre, University of Swansea or at the Cambridge University Chemical Laboratory. In Swansea, Electron Impact (EI) and Chemical Ionization (CI) low resolution spectra were carried out on a VG model 12-253 (under ACE conditions) and a Quattro II low resolution triple quadrupole MS. Accurate mass measurements for EI and CI were performed on +VG ZAB-E and Finnigan MAT 900 XLT instruments. In Cambridge FAB, EI and CI, low resolution and accurate mass, spectra were performed on a KRATOS MS-890 and on a Micromass Q-TOF instrument. Electrospray spectra were determined with an ES Bruker FTICR. All CI measurements were performed with $\mathrm{NH}_{3}$ as the carrier gas. Optical rotations were measured using a Perkin-Elmer 241 polarimeter, in a cell of $1 \mathrm{dm}$ path length. The concentration $(c)$ is expressed in $\mathrm{g} / 100 \mathrm{~mL}$ (equivalent to $\left.\mathrm{g} / 0.1 \mathrm{dm}^{3}\right)$. Specific rotations denoted as $[\alpha]_{\mathrm{D}}^{\mathrm{T}}$, imply units of ${ }^{\circ} \mathrm{dm}^{2} \mathrm{~g}^{-1}(\mathrm{~T}=$ temp $\left.{ }^{\circ} \mathrm{C}\right)$. Microanalyses were carried out by the staff of the Cambridge University Chemical Laboratory Microanalytical Department. Melting points ( $\mathrm{mp}$ ) were determined using a Kofler block or a Büchi 510 melting point apparatus and are uncorrected. Analytical thin layer chromatography (TLC) was carried out on Merck pre-coated $0.25 \mathrm{~mm}$ thick plates of Kieselgel $60 \mathrm{~F}_{254^{\circ}}$. Preparative layer chromatography was carried out on $1 \mathrm{~mm}$ thick plates $(18 \mathrm{~cm} \times 20 \mathrm{~cm})$ of Merck Kieselgel $\mathrm{PF}_{254}$. Flash chromatography ${ }^{2}$ was carried out using Merck Kieselgel 60 (230-400 mesh). Non-aqueous reactions were carried out under an atmosphere of dry argon unless indicated to the contrary. Dry THF was distilled from potassium in a recycling still using benzophenone ketyl as indicator. Other dry solvents were purified by standard techniques. ${ }^{3}$ Ether refers to diethyl ether. Light petroleum refers to 
the fraction boiling between $40{ }^{\circ} \mathrm{C}$ and $60{ }^{\circ} \mathrm{C}$. Brine refers to a saturated solution of sodium chloride in water.

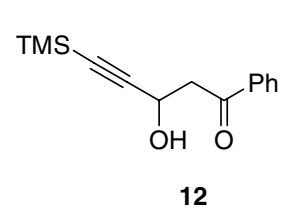

3-Hydroxy-1-phenyl-5-trimethylsilyl-pent-4-yn-1-one 12. A solution of acetophenone (150 $\mu \mathrm{L}$, $1.29 \mathrm{mmol})$ and $\mathrm{Et}_{3} \mathrm{~N}(240 \mu \mathrm{L}, 1.72 \mathrm{mmol})$ in dry $\mathrm{CH}_{2} \mathrm{Cl}_{2}(12 \mathrm{~mL})$ at $-65^{\circ} \mathrm{C}$ was treated with $\mathrm{Bu}_{2} \mathrm{BOTf}$ (1.60 $\mathrm{mL}, 1 \mathrm{M}$ in $\mathrm{CH}_{2} \mathrm{Cl}_{2}, 1.6 \mathrm{mmol}$ ), added via syringe at such a rate as to maintain the temperature below $-60{ }^{\circ} \mathrm{C}$. The mixture was stirred for $40 \mathrm{~min}$, warmed to $0{ }^{\circ} \mathrm{C}$ over $10 \mathrm{~min}$, stirred for $70 \mathrm{~min}$ and finally re-cooled to $-60{ }^{\circ} \mathrm{C}$. TMS-propynal $\mathbf{1 1 b}^{4}(168 \mathrm{mg}, 1.33 \mathrm{mmol})$ was added via cannula as a solution in $\mathrm{CH}_{2} \mathrm{Cl}_{2}(0.5 \mathrm{~mL}, 0.5 \mathrm{~mL}$ rinse $)$ and the mixture was allowed to warm to $0{ }^{\circ} \mathrm{C}$ over $1 \mathrm{~h}$. After an additional $1.5 \mathrm{~h}$ at $0{ }^{\circ} \mathrm{C}$ the reaction was quenched with a solution of methanol $(8 \mathrm{~mL}), \mathrm{pH} 7$ buffer $(4 \mathrm{~mL})$ and $\mathrm{H}_{2} \mathrm{O}_{2}(100 \mathrm{v} / \mathrm{v}, 2 \mathrm{~mL})$, allowed to warm to $20{ }^{\circ} \mathrm{C}$ and stirred for $1.5 \mathrm{~h}$. The layers were separated and the aqueous layer was extracted with $\mathrm{CH}_{2} \mathrm{Cl}_{2}(4 \times 50 \mathrm{~mL})$. The combined organic layers were washed with water $(50 \mathrm{~mL})$, dried $\left(\mathrm{MgSO}_{4}\right)$ and concentrated. The product was purified by flash chromatography (ethyl acetate:hexane, 1:9) to give the title compound $\mathbf{1 2}$ as a yellow oil (235 mg, $0.95 \mathrm{mmol}, 74 \%) ; R_{f}$ (ethyl acetate:hexane, 3:7) 0.38; ${ }^{1} \mathrm{H} \mathrm{NMR}\left(250 \mathrm{MHz}, \mathrm{CDCl}_{3}\right) \delta 7.98-7.95(\mathrm{~m}$, 2H), 7.64-7.57 (m, 1H), 7.50-7.44 (m, 2H), $5.00(\mathrm{dd}, J=8.2,3.6 \mathrm{~Hz}, 1 \mathrm{H}), 3.47(\mathrm{dd}, J=17.7,8.2 \mathrm{~Hz}$, 1H), $3.34(\mathrm{dd}, J=17.7,3.6 \mathrm{~Hz}, 1 \mathrm{H}), 3.00-2.50(\mathrm{~s}, 1 \mathrm{H}), 0.16(\mathrm{~s}, 9 \mathrm{H}) ;{ }^{13} \mathrm{C} \mathrm{NMR}\left(62.5 \mathrm{MHz}, \mathrm{CDCl}_{3}\right)$ $198.9,136.4,133.8,128.8,128.2,104.8,90.1,59.1,45.5,-0.2 ;$ IR (film) 3540-3160, $1670 \mathrm{~cm}^{-1}$; MS $\left(\mathrm{CI}, \mathrm{NH}_{3}\right) \mathrm{m} / z$ (rel intensity) $247\left[100,(\mathrm{M}+\mathrm{H})^{+}\right]$; HRMS $\left(\mathrm{CI}, \mathrm{NH}_{3}\right) \mathrm{m} / z 247.1154$ (247.1155 calcd for $\left.\mathrm{C}_{14} \mathrm{H}_{19} \mathrm{O}_{2} \mathrm{Si}, \mathrm{MH}\right)$. Anal. Calcd for $\mathrm{C}_{14} \mathrm{H}_{18} \mathrm{O}_{2} \mathrm{Si}$ : C, 68.3; H, 7.4. Found: C, 68.2; H, 7.4.

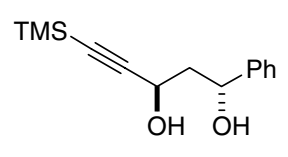


$\mathbf{1}\left(R^{*}\right), 3\left(R^{*}\right)$-1-Phenyl-5-trimethylsilyl-pent-4-yne-1,3-diol 13 . To a cooled $\left(-35{ }^{\circ} \mathrm{C}\right)$ solution of tetramethylammonium triacetoxy borohydride $(1.72 \mathrm{~g}, 6.54 \mathrm{mmol})$ in acetonitrile $(6 \mathrm{~mL})$ and dry AcOH (3 mL), $12(340 \mathrm{mg}, 1.38 \mathrm{mmol})$ was added via cannula as a solution in acetonitrile $(1 \mathrm{~mL}, 1$ $\mathrm{mL}$ rinse). The mixture was stirred for $30 \mathrm{~min}$ then warmed to $-20{ }^{\circ} \mathrm{C}$ and stirred for $18 \mathrm{~h}$. The reaction was quenched with $0.5 \mathrm{M}$ aqueous Rochelle's salt $(15 \mathrm{~mL})$ and allowed to warm to $20{ }^{\circ} \mathrm{C}$ over $2 \mathrm{~h}$. The mixture was poured onto ice, neutralized with saturated $\mathrm{NaHCO}_{3}$ solution and extracted with $\mathrm{CH}_{2} \mathrm{Cl}_{2}(3 \times 50 \mathrm{~mL})$. The aqueous layer was saturated with solid $\mathrm{NaCl}$ and extracted with EtOAc $(50$ $\mathrm{mL})$ and the combined organic layers were washed with saturated $\mathrm{NaHCO}_{3}(50 \mathrm{~mL})$, dried $\left(\mathrm{MgSO}_{4}\right)$ and concentrated in vacuo to yield the title compound $\mathbf{1 3}$ as a white solid (309 $\mathrm{mg}, 1.24 \mathrm{mmol}, \mathbf{9 0 \% )}$; $R_{f}$ (ethyl acetate:hexane, 3:7) 0.25; m.p. 92-94 ${ }^{\circ} \mathrm{C}$ (EtOAc/hexane); ${ }^{1} \mathrm{H}$ NMR (200 MHz, $\mathrm{CDCl}_{3}$ ) $\delta$ 7.38-7.28 (m, 5H), $4.63(\mathrm{~m}, 1 \mathrm{H}), 4.22(\mathrm{dd}, J=9.2,3.2 \mathrm{~Hz}, 1 \mathrm{H}), 3.00(\mathrm{~s}, 1 \mathrm{H}), 2.66(\mathrm{~s}, 1 \mathrm{H}), 2.22-2.12$ $(\mathrm{ddd}, J=14.5,9.2,4.0 \mathrm{~Hz}, 1 \mathrm{H}), 2.09-1.97(\mathrm{ddd}, J=14.5,6.4,3.2 \mathrm{~Hz}, 1 \mathrm{H}), 1.19(\mathrm{~s}, 9 \mathrm{H}) ;{ }^{13} \mathrm{C} \mathrm{NMR}$ $\left(62.5 \mathrm{MHz}, \mathrm{CDCl}_{3}\right) \delta 143.9,128.7,127.8,125.8,106.0,90.5,72.1,61.4,45.0,0.0$; IR (film) 3540$3140 \mathrm{~cm}^{-1} ; \mathrm{MS}\left(\mathrm{CI}, \mathrm{NH}_{3}\right) \mathrm{m} / z$ (rel intensity) $266\left[60,\left(\mathrm{M}+\mathrm{NH}_{4}\right)^{+}\right], 248\left[100,(\mathrm{M}+\mathrm{H})^{+}\right]$; HRMS (CI, $\left.\mathrm{NH}_{3}\right) m / z 266.1576\left(266.1577\right.$ calcd for $\mathrm{C}_{14} \mathrm{H}_{24} \mathrm{NO}_{2} \mathrm{Si}, \mathrm{MNH}_{4}$ ). Anal. Calcd for $\mathrm{C}_{14} \mathrm{H}_{20} \mathrm{O}_{2} \mathrm{Si}: \mathrm{C}, 67.7 ; \mathrm{H}$, 8.1. Found: C, 67.5; H, 8.1.

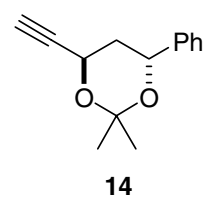

4(R $\left.{ }^{*}\right), 6\left(R^{*}\right)$-4-Ethynyl-2,2-dimethyl-6-phenyl-[1,3]dioxane, 14. A solution of 13 (285 $\mathrm{mg}, 1.15$ mmol) in $\mathrm{MeOH}(5 \mathrm{~mL})$ at $0{ }^{\circ} \mathrm{C}$ was treated with a solution of $2 \mathrm{~N}$ aqueous $\mathrm{NaOH}(5 \mathrm{~mL})$ in $\mathrm{MeOH}($ $15 \mathrm{~mL})$. After $10 \mathrm{~min}$, the mixture was diluted with water $(50 \mathrm{~mL})$ and extracted with EtOAc $(3 \times 100$ $\mathrm{mL})$. The combined organic layers were dried $\left(\mathrm{MgSO}_{4}\right)$ and concentrated in vacuo. The product was purified by flash chromatography (ethyl acetate:hexane, $1: 5)$ to give $1\left(R^{*}\right), 3\left(R^{*}\right)$-1-phenyl-pent-4-yne1,3-diol (181 mg, $1.03 \mathrm{mmol}, 89 \%)$ as a light straw-colored oil; $R_{f}$ (ethyl acetate:hexane, 3:7) $0.13 ;{ }^{1} \mathrm{H}$ 
$\operatorname{NMR}\left(200 \mathrm{MHz}, \mathrm{CDCl}_{3}\right) \delta$ 7.46-7.24 (m, 5H), $5.26(\mathrm{dd}, J=9.6,3.0 \mathrm{~Hz}, 1 \mathrm{H}), 4.67-4.62(\mathrm{~m}, 1 \mathrm{H}), 2.78$

(s, 2H), $2.55(\mathrm{~d}, J=2.2 \mathrm{~Hz}, 1 \mathrm{H}), 2.27-2.16(\mathrm{ddd}, J=14.6,9.6,3.0 \mathrm{~Hz}, 1 \mathrm{H}), 2.07-1.98(\mathrm{ddd}, J$ 14.6,

6.2, 3.0 Hz, 1H); ${ }^{13} \mathrm{C} \mathrm{NMR}\left(62.5 \mathrm{MHz}, \mathrm{CDCl}_{3}\right) \delta 143.8,128.8,128.0,125.8,84.3,73.7,72.2,60.9$, 44.6; IR (film) 3520-3100, $3270 \mathrm{~cm}^{-1}$; $\mathrm{MS}\left(\mathrm{CI}, \mathrm{NH}_{3}\right) \mathrm{m} / z$ (rel intensity) $194\left[35,\left(\mathrm{M}+\mathrm{NH}_{4}\right)^{+}\right], 176$ [100, $\left.(\mathrm{M}+\mathrm{H})^{+}\right]$; HRMS $\left(\mathrm{CI}, \mathrm{NH}_{3}\right) \mathrm{m} / z$ 194.1181 (194.1182 calcd for $\left.\mathrm{C}_{14} \mathrm{H}_{24} \mathrm{NO}_{2} \mathrm{Si}, \mathrm{MNH}_{4}\right)$. Anal. Calcd for $\mathrm{C}_{11} \mathrm{H}_{12} \mathrm{O}_{2}:$ C, 75.0; H, 6.9. Found: C, 74.7; H, 6.9.

A solution of $1\left(R^{*}\right), 3\left(R^{*}\right)$-1-phenyl-pent-4-yne-1,3-diol $(556 \mathrm{mg}, 3.16 \mathrm{mmol})$ and PPTS (136 mg, $0.541 \mathrm{mmol})$ in acetone $(6 \mathrm{~mL})$ at $0{ }^{\circ} \mathrm{C}$ was treated with 2 -methoxypropene $(0.60 \mathrm{~mL}, 6.26 \mathrm{mmol})$. After $3 \mathrm{~h}$ additional 2-methoxypropene $(0.40 \mathrm{~mL}, 4.18 \mathrm{mmol})$ was added. The mixture was stirred for $30 \mathrm{~min}$ and then poured into water $(30 \mathrm{~mL})$ and extracted with EtOAc $(3 \times 50 \mathrm{~mL})$. The combined organic layers were washed with brine $(50 \mathrm{~mL})$, dried $\left(\mathrm{MgSO}_{4}\right)$ and concentrated in vacuo. Purification by flash chromatography (ethyl acetate:hexane, 1:19) afforded the acetonide 14 (613 mg, $2.83 \mathrm{mmol}, 90 \%)$ as a clear colorless oil; $R_{f}$ (ethyl acetate:hexane, 3:7) $0.63 ;{ }^{1} \mathrm{H}$ NMR (400 MHz, $\left.\mathrm{C}_{6} \mathrm{D}_{6}\right) \delta 7.35-7.32(\mathrm{~m}, 2 \mathrm{H}), 7.26-7.10(\mathrm{~m}, 3 \mathrm{H}), 5.25(\mathrm{dd}, J=10.9,3.5 \mathrm{~Hz}, 1 \mathrm{H}), 4.73(\mathrm{~m}, 1 \mathrm{H}), 2.07(\mathrm{~d}, J$ $=2.3 \mathrm{~Hz}, 1 \mathrm{H}), 2.02-1.91(\mathrm{~m}, 1 \mathrm{H}), 1.86-1.75(\mathrm{~m}, 1 \mathrm{H}), 1.79(\mathrm{~s}, 3 \mathrm{H}), 1.55(\mathrm{~s}, 3 \mathrm{H}) ;{ }^{13} \mathrm{C} \mathrm{NMR}(62.5 \mathrm{MHz}$, $\left.\mathrm{CDCl}_{3}\right) \delta 142.6,128.7,127.7,126.3,100.9,85.1,74.3,68.1,60.4,38.8,23.7$; IR (film) $3270 \mathrm{~cm}^{-1}$.

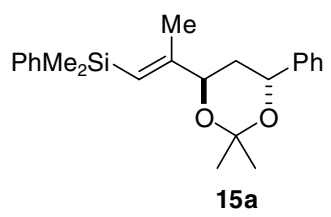

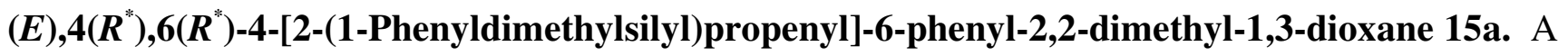
cooled $\left(-20^{\circ} \mathrm{C}\right)$ solution of phenyldimethylsilyllithium $(1.4 \mathrm{mmol})$ in THF $(10 \mathrm{~mL})$ was added to a dry flask containing $\mathrm{CuCN}(62.8 \mathrm{mg}, 0.70 \mathrm{mmol})$, and the dark red solution was stirred at $0{ }^{\circ} \mathrm{C}$ for $45 \mathrm{~min}$. The mixture was cooled to $-60{ }^{\circ} \mathrm{C}$ and treated with a solution of the alkyne $14(111 \mathrm{mg}, 0.513 \mathrm{mmol})$ in THF (3 mL). After $10 \mathrm{~min}$ the mixture was allowed to warm to $0{ }^{\circ} \mathrm{C}$, was stirred for $45 \mathrm{~min}$ and 
was then treated with $\mathrm{MeI}(150 \mu \mathrm{L}, 2.41 \mathrm{mmol})$. The mixture was allowed to warm to $20{ }^{\circ} \mathrm{C}$ and stirred for $14 \mathrm{~h}$ after which the red color had faded. The reaction was quenched by the addition of saturated aqueous $\mathrm{NH}_{4} \mathrm{Cl}(15 \mathrm{~mL})$, diluted with water $(50 \mathrm{~mL})$ and extracted with EtOAc $(3 \times 100$ $\mathrm{mL})$. The combined organic layers were washed with brine $(100 \mathrm{~mL})$, dried $\left(\mathrm{MgSO}_{4}\right)$ and concentrated in vacuo. Purification by flash chromatography (ethyl acetate:hexane, 1:49) provided the title compound 15a (106 mg, $0.289 \mathrm{mmol}, 56 \%)$ as well as some recovered 14 (54.7 $\mathrm{mg}, 0.253 \mathrm{mmol}$, 49\%; including minor impurities). Data for $15 a ; R_{f}$ (ethyl acetate:hexane, $\left.1: 19\right) 0.13 ;{ }^{1} \mathrm{H}$ NMR (250 $\left.\mathrm{MHz}, \mathrm{C}_{6} \mathrm{D}_{6}\right) \delta 7.63-7.50(\mathrm{~m}, 2 \mathrm{H}), 7.37-7.10(\mathrm{~m}, 8 \mathrm{H}), 5.99(\mathrm{~s}, 1 \mathrm{H}), 4.90(\mathrm{dd}, J=9.2,6.8 \mathrm{~Hz}, 1 \mathrm{H}), 4.36$ $(\mathrm{t}, J=7.9 \mathrm{~Hz}, 1 \mathrm{H}), 2.06-1.88(\mathrm{~m}, 2 \mathrm{H}), 1.72(\mathrm{~s}, 3 \mathrm{H}), 1.46(\mathrm{~s}, 3 \mathrm{H}), 1.45(\mathrm{~s}, 3 \mathrm{H}), 0.42(\mathrm{~s}, 6 \mathrm{H}) ;{ }^{13} \mathrm{C} \mathrm{NMR}$ $\left(250 \mathrm{MHz}, \mathrm{C}_{6} \mathrm{D}_{6}\right) \delta 156.2,143.4,139.8,134.1,129.2,128.5,127.4,126.1,119.8,101.1,72.1,68.8$, 40.1, 25.1, 25.0, 18.3, -0.8; IR (film) $1625,1175 \mathrm{~cm}^{-1}$; MS (CI, NH $\mathrm{NH}_{3} \mathrm{~m} /$ (rel intensity) $367[2,(\mathrm{M}+$ $\left.\mathrm{H})^{+}\right]$.

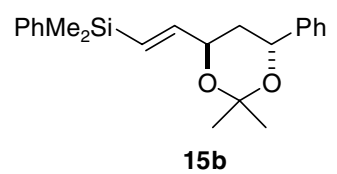

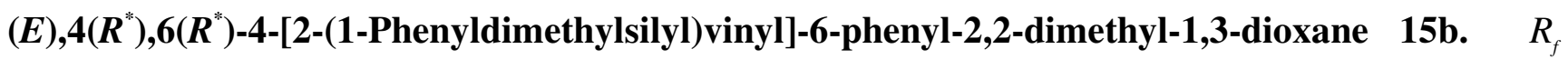
(ethyl acetate:hexane, 1:9) 0.40; ${ }^{1} \mathrm{H} \mathrm{NMR}\left(250 \mathrm{MHz}, \mathrm{CDCl}_{3}\right) \delta$ 7.55-7.49 (m, 2H), 7.33-7.09 (m, 8H), $6.31(\mathrm{dd}, J=18.9,4.2 \mathrm{~Hz}, 1 \mathrm{H}), 6.09(\mathrm{dd}, J 18.9,1.2 \mathrm{~Hz}, 1 \mathrm{H}), 4.87(\mathrm{dd}, J=9.0,6.7 \mathrm{~Hz}, 1 \mathrm{H}), 4.50-4.40$ (m, 1H), 1.93-1.83 (m , 2H), $1.44(\mathrm{~s}, 3 \mathrm{H}), 1.43(\mathrm{~s}, 3 \mathrm{H}), 0.32(\mathrm{~s}, 6 \mathrm{H})$; IR (film) $1620 \mathrm{~cm}^{-1}$.

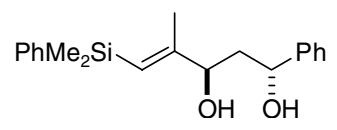

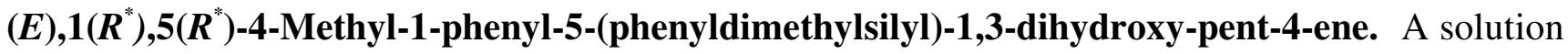
of the acetonide $\mathbf{1 5 a}(100 \mathrm{mg}, 0.27 \mathrm{mmol})$ in THF $(2 \mathrm{~mL})$ was stirred vigorously with $1 \mathrm{~N} \mathrm{HCl}(2 \mathrm{~mL})$ at $20{ }^{\circ} \mathrm{C}$ for $1.5 \mathrm{~h}$. The mixture was dissolved in water $(20 \mathrm{~mL})$ and extracted with EtOAc $(2 \times 50$ 
$\mathrm{mL})$. The combined organic extracts were washed with water $(20 \mathrm{~mL})$, dried $\left(\mathrm{MgSO}_{4}\right)$ and concentrated in vacuo. Purification by flash chromatography (ethyl acetate:hexane, 1:49 $\rightarrow 1: 9$ ) yielded the title compound (45.6 mg, $0.14 \mathrm{mmol}, 52 \%$ ); $R_{f}$ (ethyl acetate:hexane, 3:7) 0.23; ${ }^{1} \mathrm{H}$ NMR $\left(400 \mathrm{MHz}, \mathrm{CDCl}_{3}\right) \delta$ 7.54-7.49 (m, 2H), 7.40-7.25 (m, 8H), $5.78(\mathrm{~s}, 1 \mathrm{H}), 4.98(\mathrm{dd}, J=8.9,2.8 \mathrm{~Hz}$, 1H), $4.29(\mathrm{dd}, J=7.6,2.9 \mathrm{~Hz}, 1 \mathrm{H}), 2.05(\mathrm{ddd}, J=14.6,8.8,3.3 \mathrm{~Hz}, 1 \mathrm{H}), 1.89$ (ddd, $J=14.7,7.6,2.9$ Hz, 1H), 1.67 (s, 3H), 0.42 (s, 6H); IR (film) 3520-3200, $1605 \mathrm{~cm}^{-1}$.

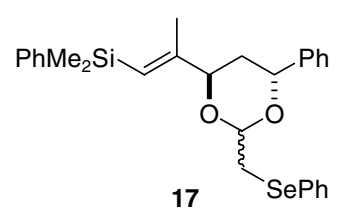

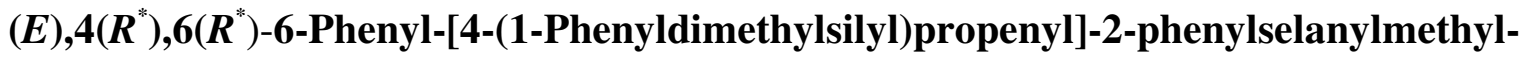

[1,3]dioxane, 17. A solution of the diol $(E), 1\left(R^{*}\right), 5\left(R^{*}\right)-4-m e t h y l-1-p h e n y l-5-($ phenyldimethylsilyl)1,3-dihydroxy-pent-4-ene (48.3 mg, $0.148 \mathrm{mmol})$, phenylselenoacetaldehyde diethylacetal 16 (52.1 $\mathrm{mg}, 0.191 \mathrm{mmol})$ and PPTS $(c a .5 \mathrm{mg})$ in toluene $(2 \mathrm{~mL})$ was heated at reflux for $1 \mathrm{~h}$. The mixture was then poured into water $(50 \mathrm{~mL})$ and extracted with $\mathrm{Et}_{2} \mathrm{O}(3 \times 50 \mathrm{~mL})$. The combined organic layers were washed with water $(20 \mathrm{~mL})$, dried $\left(\mathrm{MgSO}_{4}\right)$ and evaporated in vacuo. Purification by flash chromatography (diethyl ether:hexane, 3:97) gave the title compound (47.6 $\mathrm{mg}, 0.094 \mathrm{mmol}, 63 \%$ ) as a clear colorless oil; $R_{f}$ (ethyl acetate:hexane, $\left.1: 9\right) 0.53 ;{ }^{1} \mathrm{H}$ NMR $\left(200 \mathrm{MHz}, \mathrm{CDCl}_{3}\right) \delta$ (mixture of diastereomers) 7.57-7.14 (m, 15H), 5.82 and $5.69(2 \times \mathrm{s}, 1 \mathrm{H}), 5.34-5.32(\mathrm{~m}, 0.5 \mathrm{H}), 5.15-4.98(\mathrm{~m}, 1 \mathrm{H})$, 4.60-4.59 (m, 0.5H), 4.14-4.05 (m, 1H), 3.12-3.07 (m, 2H), 2.33-2.16 (m, 2H), 1.82 and $1.72(2 \times \mathrm{s}$, $3 \mathrm{H}), 0.42$ and $0.39(2 \times \mathrm{s}, 6 \mathrm{H})$.

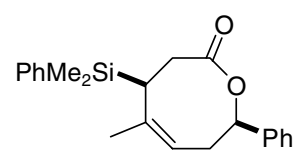


solution of the selenides $17(28 \mathrm{mg}, 55 \mu \mathrm{mol})$ in a mixture of methanol (6 mL, water $(1 \mathrm{~mL})$ and ethyl acetate $(2 \mathrm{~mL})$ was added sodium hydrogencarbonate $(24 \mathrm{mg}, 0.8 \mathrm{mmol})$ and sodium periodate (58 $\mathrm{mg}, 0.7 \mathrm{mmol})$. The resulting suspension was stirred for $1.5 \mathrm{~h}$ and was then poured into water. Ethyl acetate and hexane were added and the organic phase was separated, dried $\left(\mathrm{MgSO}_{4}\right)$ and concentrated in vасио. Residual solvent was removed under reduced pressure for $18 \mathrm{~h}$ to give the corresponding selenoxides which were used in the next reaction without further purification. The selenoxides were dissolved in xylene (4 mL), 1-tert-butyldimethylsiloxy-1-methoxy-ethene $\mathbf{1 8}$ (806 mg, $4.28 \mathrm{mmol})$ and DBU (40 $\mu \mathrm{L}, 0.27 \mathrm{mmol})$ were added. The resulting solution was heated in a $\mathrm{NaOH}$-washed sealed tube at $185^{\circ} \mathrm{C}$ for $5 \mathrm{~h}$. The xylene was removed under high vacuum and the residue subjected to flash chromatography (ethyl acetate:hexane, 1:19 to 1:9) to provide the title lactone 9 (6 $\mathrm{mg}, 0.017 \mathrm{mmol}$, $31 \%$ ); $R_{f}$ (ethyl acetate:hexane, 1:9) 0.28; ${ }^{1} \mathrm{H}$ NMR $\left(400 \mathrm{MHz}, \mathrm{C}_{6} \mathrm{D}_{6}\right) \delta 7.24-7.03(\mathrm{~m}, 10 \mathrm{H}), 5.18(\mathrm{t}, J=$ $8.7 \mathrm{~Hz}, 1 \mathrm{H}), 5.12(\mathrm{t}, J=8.5 \mathrm{~Hz}, 1 \mathrm{H}), 2.39(\mathrm{t}, J=12.5 \mathrm{~Hz}, 1 \mathrm{H}), 2.34(\mathrm{dd}, J=12.5,6.4 \mathrm{~Hz}, 1 \mathrm{H}), 2.22-$ $2.17(\mathrm{~m}, 2 \mathrm{H}), 2.13-2.08(\mathrm{~m}, 1 \mathrm{H}), 1.51(\mathrm{~s}, 3 \mathrm{H}), 0.10(\mathrm{~s}, 3 \mathrm{H}), 0.05(\mathrm{~s}, 3 \mathrm{H}) ;{ }^{13} \mathrm{C} \mathrm{NMR}\left(400 \mathrm{MHz}, \mathrm{C}_{6} \mathrm{D}_{6}\right) \delta$ $174.0,142.3,141.5,137.0,134.2,129.6,128.7,125.8,118.5,75.6,37.6,33.6,33.4,26.7,-3.6,-3.9$; IR (film) $1720 \mathrm{~cm}^{-1} ; \mathrm{MS}\left(\mathrm{CI}, \mathrm{NH}_{3}\right) \mathrm{m} / z$ (rel intensity) $351\left[16,(\mathrm{M}+\mathrm{H})^{+}\right]$; HRMS $\left(\mathrm{CI}, \mathrm{NH}_{3}\right) \mathrm{m} / z$ 351.1780 (351.1781 calcd for $\mathrm{C}_{22} \mathrm{H}_{27} \mathrm{O}_{2} \mathrm{Si}, \mathrm{MH}$ ).

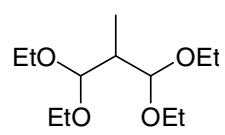

1,1,3,3-Tetraethoxy-2-methyl-propane. ${ }^{5}$ To degassed triethyl orthoformate $(100.5 \mathrm{~mL}, 600 \mathrm{mmol})$ was added boron trifluoride etherate $(0.42 \mathrm{~mL}, 3.0 \mathrm{mmol})$ followed by the dropwise addition of ethyl 1-propenyl ether $(33.0 \mathrm{~mL}, 300 \mathrm{mmol})$ maintaining the temperature below $45^{\circ} \mathrm{C}$. After the addition was complete $(10 \mathrm{~min})$, the mixture was heated at $45^{\circ} \mathrm{C}$ for $1 \mathrm{~h}$. Solid sodium carbonate $(3.0 \mathrm{~g})$ was added and stirring was continued for a further $3 \mathrm{~h}$ after which the mixture was allowed to cool. Purification via reduced pressure distillation provided the title compound as a clear and colorless 
liquid (62.0 g, $260 \mathrm{mmol}, 88 \%)$; bp 60-65 ${ }^{\circ} \mathrm{C} / 0.3 \mathrm{~mm} \mathrm{Hg} ;{ }^{1} \mathrm{H}$ NMR $\left(250 \mathrm{MHz}, \mathrm{CDCl}_{3}\right) \delta 4.43(\mathrm{~d}, J=$ $5.7 \mathrm{~Hz}, 2 \mathrm{H}), 3.73-3.45(\mathrm{~m}, 8 \mathrm{H}), 2.09-1.95(\mathrm{~m}, 1 \mathrm{H}), 1.20(\mathrm{td}, J=7.0,3.1 \mathrm{~Hz}, 12 \mathrm{H}), 0.95(\mathrm{~d}, J=6.9$ $\mathrm{Hz}, 3 \mathrm{H})$.

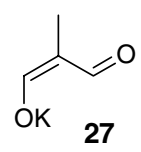

Potassium 2-methyl-3-oxo-propen-1-olate 27. From 1,1,3,3-tetraethoxy-2-methyl-propane. ${ }^{6}$

Hydrochloric acid (6 M, 17.0 mL) was added to a stirring solution of 1,1,3,3-tetraethoxy-2-methylpropane and the mixture was stirred at $80{ }^{\circ} \mathrm{C}$ for $1 \mathrm{~h}$ resulting in the reaction mixture becoming a dark amber color developed. The mixture was then cooled in an ice bath and adjusted to pH 13 with $5 \mathrm{M}$ aqueous potassium hydroxide solution $(45 \mathrm{~mL})$. The crude residue was washed with ether $(20 \mathrm{~mL})$ and the aqueous layer was concentrated under vacuum $(15 \mathrm{~mm} \mathrm{Hg})$ for 1 hour. The resultant solid was re-dissolved in hot absolute ethanol, as filtered and re-concentrated to a yield a light brown solid. The product was dried at $90-100{ }^{\circ} \mathrm{C}$ under high vacuum to provide the title compound 27 (13.3 g, 0.107 mmol, 87\%). The salt was used in the next step without further purification; ${ }^{1} \mathrm{H}$ NMR $(250 \mathrm{MHz}$, DMSO-d $\left._{6}\right) \delta 8.45(\mathrm{~s}, 2 \mathrm{H}), 1.32(\mathrm{~s}, 3 \mathrm{H})$. From 3-ethoxymethacrolein. 3-Ethoxymethacrolein $(4.0 \mathrm{~mL}$, $34 \mathrm{mmol})$ was added to aqueous hydrochloric acid $(5 \mathrm{M}, 5.5 \mathrm{~mL})$ and the solution was heated at $80{ }^{\circ} \mathrm{C}$ for $1 \mathrm{~h}$. The reaction mixture was cooled in an ice bath and was adjusted to $\mathrm{pH} 13$ with aqueous potassium hydroxide solution $(3 \mathrm{M})$. The solution was washed with ether $(2 \times 50 \mathrm{~mL})$ and the water was removed under high vacuum. The resultant solid was azeotroped twice with toluene and then dissolved in ethanol $(50 \mathrm{~mL})$. The resultant mixture was heated and then filtered to remove solid impurities. The filtrate was concentrated to provide the title compound $\mathbf{2 7}$ as a yellow-orange solid (2.64 g, $21 \mathrm{mmol}, 63 \%)$. 


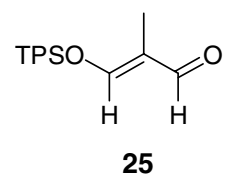

(E)-3-(tert-Butyldiphenylsilyloxy)-2-methyl-propenal 25. To a solution of the potassium salt 27 $(2.38 \mathrm{~g}, 19.2 \mathrm{mmol})$ and triethylamine $(3.20 \mathrm{~mL}, 23 \mathrm{mmol})$ in $\mathrm{Et}_{2} \mathrm{O}(18 \mathrm{~mL})$ at $-10{ }^{\circ} \mathrm{C}$ was added tertbutyldiphenylsilyl chloride $(10 \mathrm{~mL}, 38.5 \mathrm{mmol})$ as a solution in $\mathrm{Et}_{2} \mathrm{O}(10 \mathrm{~mL})$ at such a rate so as to maintain the temperature below $-5^{\circ} \mathrm{C}$. The reaction was allowed to warm slowly to room temperature with stirring for $16 \mathrm{~h}$ during which time a white precipitate formed. The mixture was filtered and the solvent removed in vacuo. Purification by Kugelrohr distillation $\left(0.75 \mathrm{~mm} \mathrm{Hg}, 180-195{ }^{\circ} \mathrm{C}\right)$ provided the aldehyde 25 as a clear gum $(2.68 \mathrm{~g}, 8.25 \mathrm{mmol}, 43 \%) ; R_{f}$ (ethyl acetate:hexane, 1:4) 0.5; ${ }^{1} \mathrm{H}$ NMR $\left(250 \mathrm{MHz}, \mathrm{CDCl}_{3}\right) \delta 9.16(\mathrm{~s}, 1 \mathrm{H}), 7.65-7.63(\mathrm{~m}, 4 \mathrm{H}) 7.52-7.25(\mathrm{~m}, 6 \mathrm{H}), 7.06(\mathrm{q}, J=1.1 \mathrm{~Hz}, 1 \mathrm{H}), 1.85$ $(\mathrm{d}, J=1.1 \mathrm{~Hz}, 3 \mathrm{H}), 1.13(\mathrm{~s}, 9 \mathrm{H}) ; \mathrm{IR}\left(\mathrm{CHCl}_{3}\right) 1743(\mathrm{CO}) \mathrm{cm}^{-1} ;{ }^{13} \mathrm{C} \mathrm{NMR}\left(62.5 \mathrm{MHz}, \mathrm{CDCl}_{3}\right)$ 192.9, $162.8,135.3,130.9,130.7,128.2,124.3,26.5,19.3,6.5$; IR (film) $1678 \mathrm{~cm}^{-1} ; \mathrm{MS}\left(\mathrm{CI}, \mathrm{NH}_{3}\right) \mathrm{m} / z$ (rel intensity) $235\left[100,(\mathrm{M}+\mathrm{H})^{+}\right]$; HRMS $\left(\mathrm{CI}, \mathrm{NH}_{3}\right) \mathrm{m} / z \quad 325.1624$ (325.1625 calcd for $\left.\mathrm{C}_{14} \mathrm{H}_{19} \mathrm{O}_{2} \mathrm{Si}, \mathrm{MH}\right)$.

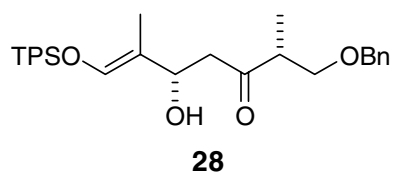

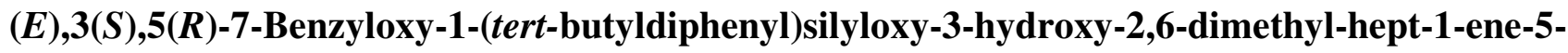

one 28. To a cooled $\left(0{ }^{\circ} \mathrm{C}\right)$ solution of $(+)-\mathrm{Ipc}_{2} \mathrm{BCl}(1.82 \mathrm{~g}, 5.67 \mathrm{mmol})$ in $\mathrm{Et}_{2} \mathrm{O}(30 \mathrm{~mL})$ was added triethylamine $(0.8 \mathrm{~mL}, 5.74 \mathrm{mmol})$ followed by a solution of the ketone $\mathbf{2 6}^{7}(890 \mathrm{mg}, 4.63 \mathrm{mmol})$ as a solution in $\mathrm{Et}_{2} \mathrm{O}(15 \mathrm{~mL})$ and the resultant white suspension was stirred for $2.5 \mathrm{~h}$. The mixture was cooled to $-78{ }^{\circ} \mathrm{C}$ and a solution of the aldehyde $25(1.50 \mathrm{~g}, 4.6 \mathrm{mmol})$ in $\mathrm{Et}_{2} \mathrm{O}(10 \mathrm{~mL})$ was added dropwise. The reaction mixture was maintained at $-78{ }^{\circ} \mathrm{C}$ for $2 \mathrm{~h}$ and then at $-40{ }^{\circ} \mathrm{C}$ for $1 \mathrm{~h}$. The reaction was quenched by the addition of a mixture of methanol $(60 \mathrm{~mL}), \mathrm{pH} 7$ buffer $(16 \mathrm{~mL})$ and $\mathrm{H}_{2} \mathrm{O}_{2}(100 \mathrm{v} / \mathrm{v}, 4 \mathrm{~mL})$ and the biphasic system was stirred vigorously at $0{ }^{\circ} \mathrm{C}$ for $10 \mathrm{~min}$ and then at 
room temperature for $1 \mathrm{~h}$. The mixture was extracted with $\mathrm{CH}_{2} \mathrm{Cl}_{2}(3 \times 50 \mathrm{~mL})$ then $\mathrm{Et}_{2} \mathrm{O}(50 \mathrm{~mL})$. The combined organic extracts were dried $\left(\mathrm{MgSO}_{4}\right)$ and then concentrated in vacuo. Purification by flash chromatography (hexane:EtOAc, $20: 1 \rightarrow 10: 1)$ provided $28(1.31 \mathrm{~g}, 2.53 \mathrm{mmol}$, 55\%) as a clear and colorless oil; $R_{f} 0.20$ (hexane:ethyl acetate, $\left.4: 1\right) ;[\alpha]_{D}^{22}-13.8\left(c 0.92, \mathrm{CHCl}_{3}\right) ;{ }^{1} \mathrm{H} \mathrm{NMR}(400 \mathrm{MHz}$, $\left.\mathrm{CDCl}_{3}\right) \delta$ 7.65-7.62 (m, 4H), 7.64-7.23 (m, 11H), 6.34 (br s, 1H), $4.44(\mathrm{~m}, 2 \mathrm{H}), 4.38(\mathrm{~m}, 1 \mathrm{H}), 3.57$ (dd, $J$ 9.0, 8.0 Hz, 2H), $3.44(\mathrm{dd}, J 9.0,5.2 \mathrm{~Hz}, 1 \mathrm{H}), 2.90-2.75(\mathrm{~m}, 3 \mathrm{H}), 2.54(\mathrm{dd}, J 17.2,2.6,1 \mathrm{H}), 1.75$ (br s, 3H), 1.07 (s, 9H), 0.89 (d, J 7.0 Hz, 3H); $\left.{ }^{13} \mathrm{C} \mathrm{NMR} \mathrm{(100} \mathrm{MHz,} \mathrm{CDCl}_{3}\right) \delta 213.8,137.9,137.4,135.4$, $132.9,132.7,130.0,128.4,127.8,127.7,127.6,118.0,73.3,72.1,69.3,47.7,46.9,26.6,19.3,13.2$, 8.7; IR (film) 3460, 1709, $1670 \mathrm{~cm}^{-1}$; MS (FAB) $\mathrm{m} / z$ (rel intensity) 515 [7, (M-H)]; HRMS (FAB) $\mathrm{m} / z$ 515.2645 (515.2619 calcd for $\left.\mathrm{C}_{32} \mathrm{H}_{39} \mathrm{O}_{4} \mathrm{Si}, \mathrm{M}-\mathrm{H}\right)$.

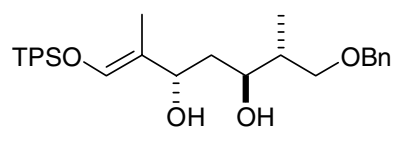

29

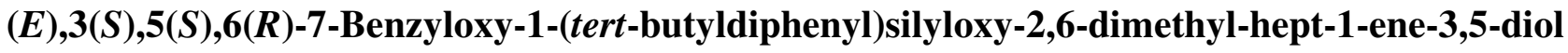

29. To a solution of tetramethylammonium triacetoxyborohydride ( $3.76 \mathrm{~g}, 14.3 \mathrm{mmol})$ in acetonitrile $(8 \mathrm{~mL})$ and acetic acid $(2 \mathrm{~mL})$ at $-50{ }^{\circ} \mathrm{C}$ was added a cooled solution of $28(305 \mathrm{mg}, 0.59 \mathrm{mmol})$ as a solution in acetonitrile $(8 \mathrm{~mL})$. The reaction mixture was allowed to warm to $-30{ }^{\circ} \mathrm{C}$ over 30 min and was maintained at that temperature for $20 \mathrm{~h}$. A saturated solution of sodium potassium tartrate $(6 \mathrm{~mL})$ was added. The mixture was allowed to come to room temperature and was stirred for $50 \mathrm{~min}$. The mixture was poured onto ice and was neutralized with saturated aqueous sodium hydrogencarbonate. The mixture was extracted with $\mathrm{CH}_{2} \mathrm{Cl}_{2}(3 \times 100 \mathrm{~mL})$. The aqueous phase was saturated with sodium chloride and was then extracted with EtOAc $(100 \mathrm{~mL})$. The combined organic phases were washed with saturated aqueous sodium hydrogencarbonate and then dried $\left(\mathrm{MgSO}_{4}\right)$. After filtration the product 29 was stored in solution at $-20{ }^{\circ} \mathrm{C}$ and was used without purification $(266 \mathrm{mg}, 0.51 \mathrm{mmol}$, 89\%); $R_{f} 0.38$ (ethyl acetate:hexane, 2:3); ${ }^{1} \mathrm{H}$ NMR (400 MHz, $\left.\mathrm{CDCl}_{3}\right) \delta$ 7.67-7.64 (m, 4H), 7.43-7.22 
(m, 11H), 6.38 (br s, 1H), $4.97(\mathrm{~s}, 2 \mathrm{H}), 4.25$ (br d, J 9.1 Hz, 1H), 3.83 (d, J 2.6 Hz) 3.75 (tt, J 7.8, 2.6, 1H), 3.64-3.54 (m, 1H), 3.50-3.43 (m, 1H), $2.61(\mathrm{~d}, J 2.6 \mathrm{~Hz}, 1 \mathrm{H}), 1.96-1.84(\mathrm{~m}, 2 \mathrm{H}), 1.75$ (br s, 3H), 1.50 (ddd, $J$ 14.3, 7.8, 2.6 Hz 1H), $1.08(\mathrm{~s}, 9 \mathrm{H}), 0.81(\mathrm{~d}, J=6.9 \mathrm{~Hz}, 3 \mathrm{H}) ;{ }^{13} \mathrm{C} \mathrm{NMR}\left(100 \mathrm{MHz}, \mathrm{CDCl}_{3}\right)$ $\delta 136.7,135.4,133.0,129.9,128.5,128.4,127.8,127.7,127.6,119.8,75.6,74.3,73.5,70.5,38.9$, 37.9, 26.6, 19.3, 13.7, 8.9; IR (film) $3242,1669 \mathrm{~cm}^{-1}$.

Assignment of the relative stereochemistry of 29 by $J$ value comparison with the diol derived from 15a.
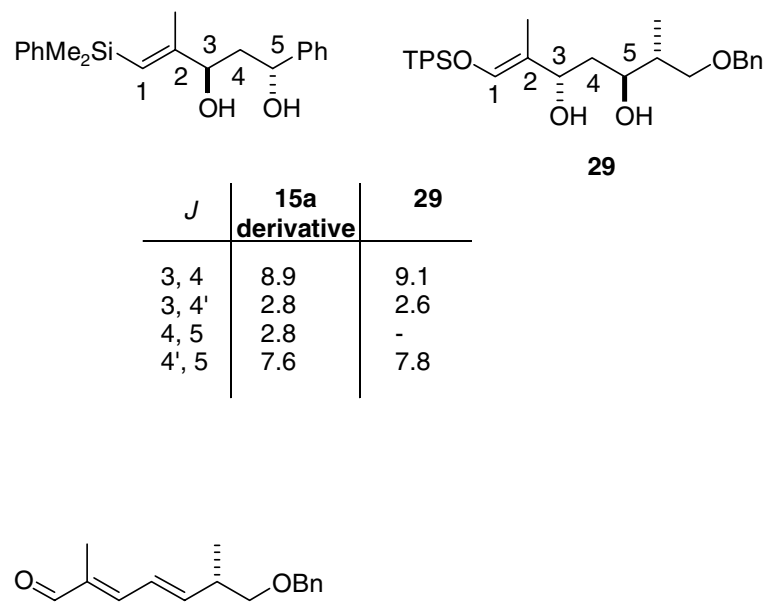

30

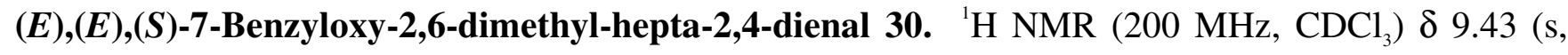
1H), 7.41-7.23 (m, 5H), $6.83(\mathrm{dd}, J 11.0,1.0 \mathrm{~Hz}, 1 \mathrm{H}), 6.46(\mathrm{ddd}, J 15.0,11.0,1.0 \mathrm{~Hz}, 1 \mathrm{H}), 6.22(\mathrm{dd}, J$ 15.0, 7.3 Hz, 1H), $4.53(\mathrm{~s}, 2 \mathrm{H}), 3.42(\mathrm{~d}, J 6.5 \mathrm{~Hz}, 2 \mathrm{H}), 2.74-2.67$ (m, 1H), 1.84 (d, J 1.0 Hz, 3H), 1.12 (d, J 7.5 Hz, 3H); IR (film) 1679, $1633 \mathrm{~cm}^{-1}$.

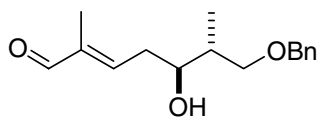

31

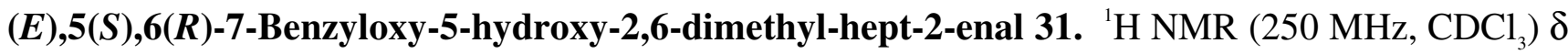
$9.44(\mathrm{~s}, 1 \mathrm{H}), 7.40-7.31(\mathrm{~m}, 5 \mathrm{H}), 6.72$ (br t, J $7.5 \mathrm{~Hz}, \mathrm{H}) 4.54$ (s, 2H), 3.83 (br s, 1H), 3.80-3.72 (m, 
1H), 3.67 (dd, J 10.0, $5.0 \mathrm{~Hz}, 1 \mathrm{H}), 3.49(\mathrm{dd}, \mathrm{t}, J 10 \mathrm{~Hz}, 1 \mathrm{H}), 2.60-2.44(\mathrm{~m}, 2 \mathrm{H}), 2.01-1.88(\mathrm{~m}, 1 \mathrm{H})$, 1.76 (br s, 3H), 0.91 (d, J 7.5 Hz, 3H).

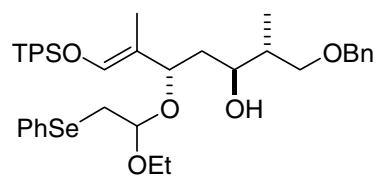

33

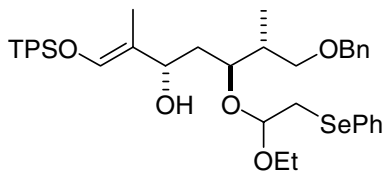

32

$(E), 2(R), 3(S), 4(S)$-1-Benzyloxy-7-(t-butyldiphenylsilyl)oxy-5-(1-ethoxy-2-phenylselanyl-ethoxy)2,6-dimethyl-hept-6-en-3-ol 33 and $(E), 2(R), 3(S), 4(S)$-7-benzyloxy-1-(t-butyldiphenylsilyl)oxy-5(1-ethoxy-2-phenylselanyl-ethoxy)-2,6-dimethyl-hept-1-en-3-ol 32. To a solution of $\mathrm{PhSeCl}(63$ $\mathrm{mg}, 0.33 \mathrm{mmol})$ in THF $(2 \mathrm{~mL})$ at room temperature was added ethyl vinyl ether $(32 \mu \mathrm{L}, 0.33 \mathrm{mmol})$ which caused the color of the solution to change from orange to yellow. The solution was stirred for $30 \mathrm{~min}$. In a separate flask, a solution of the diol $29(85 \mathrm{mg}, 0.16 \mathrm{mmol})$ in THF (5 mL) was stirred for 30 min over $4 \AA$ molecular sieves. The diol was treated with diisopropylamine (46 $\mu \mathrm{L}, 0.33 \mathrm{mmol})$ followed by the $\mathrm{PhSeCl} /$ ethyl vinyl ether solution and the mixture was stirred for 3 days at room temperature. The reaction mixture was filtered and diluted (1:1 mixture, EtOAc:hexanes, $20 \mathrm{~mL})$. The organic phase was washed with water, brine and then dried $\left(\mathrm{MgSO}_{4}\right)$. Purification by flash chromatography (hexanes:EtOAc, 50:1 $\rightarrow 100: 7)$ provided the acetals $33(44 \mathrm{mg}, 57 \mu \mathrm{mol})$ and 32 (25 $\mathrm{mg}, 32 \mu \mathrm{mol})$ in a combined yield of 55\%; Data for 33: $R_{f}$ (EtOAc:hexane, 1:9) 0.17; ${ }^{1} \mathrm{H}$ NMR (400 $\left.\mathrm{MHz}, \mathrm{CDCl}_{3}\right) \delta$ 7.64-7.60 (m, 4H), 7.45-7.24 (m, 14H), 7.05-7.00 (m, 2H), $6.17(\mathrm{q}, J 1.0 \mathrm{~Hz}, 1 \mathrm{H}), 4.48$ (s, 2H), $4.39(\mathrm{dd}, J$ 6.6, $3.5 \mathrm{~Hz}, 1 \mathrm{H}), 3.84(\mathrm{dd}, J$ 10.4, $2.5 \mathrm{~Hz}, 1 \mathrm{H}) 3.76-3.72(\mathrm{~m}, 1 \mathrm{H}), 3.66-3.38(\mathrm{~m}$, 3H), $3.34(\mathrm{~d}, J 3.7 \mathrm{~Hz}, 1 \mathrm{H}), 3.30-3.20(\mathrm{~m}, 1 \mathrm{H}), 3.10(\mathrm{dd}, J 12.7,3.5 \mathrm{~Hz}, 1 \mathrm{H}), 3.01(\mathrm{dd}, J 12.7,6.6 \mathrm{~Hz}$, 1H), 1.96-1.89 (m, 1H), 1.82-1.70 (m, 1H), $1.73(\mathrm{~d}, J 1.0 \mathrm{~Hz}, 3 \mathrm{H}), 1.34-1.28(\mathrm{~m}, 1 \mathrm{H}), 1.10(\mathrm{t}, J 7.1 \mathrm{~Hz}$, 
3H), $1.06(\mathrm{~s}, 9 \mathrm{H}), 0.88(\mathrm{~d}, J 7.0 \mathrm{~Hz}, 3 \mathrm{H})$. Data for 32: $R_{f}$ (EtOAc:hexane, 1:9) 0.09; ${ }^{1} \mathrm{H}$ NMR (200 $\left.\mathrm{MHz}, \mathrm{CDCl}_{3}\right) \delta$ 7.65-7.62 (m, 4H), 7.53-7.17 (m, 16H), $6.25(\mathrm{q}, J 1.0 \mathrm{~Hz}, 1 \mathrm{H}), 4.50(\mathrm{~s}, 2 \mathrm{H}), 4.47(\mathrm{t}, J$ 5.6 Hz, 1H), 4.09-4.02 (m, 1H), 3.76-3.68 (m, 1H), 3.57-3.41 (m, 2H), 3.40-3.24 (m, 2H), $3.18(\mathrm{~d}, J$ $4.2 \mathrm{~Hz}, 1 \mathrm{H}), 3.05-3.01(\mathrm{~m}, 2 \mathrm{H}), 1.97-1.70(\mathrm{~m}, 2 \mathrm{H}), 1.73(\mathrm{~d}, J 1.1 \mathrm{~Hz}, 3 \mathrm{H}), 1.45-1.31(\mathrm{~m}, 1 \mathrm{H}), 1.09$ (s, 9H), $1.00(\mathrm{t}, J 7.1 \mathrm{~Hz}, 3 \mathrm{H}), 0.94(\mathrm{~d}, J 6.9 \mathrm{~Hz}, 3 \mathrm{H})$.

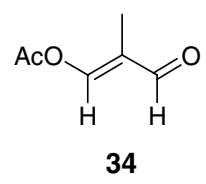

3-Acetoxy-2-methylpropenal 34. To a suspension of 27 (4.0 g, $32.3 \mathrm{mmol})$ in $^{2} \mathrm{Et}_{2} \mathrm{O}(30 \mathrm{~mL})$ and triethylamine $(6.5 \mathrm{~mL}, 47.1 \mathrm{mmol})$ at $-10{ }^{\circ} \mathrm{C}$ was added a solution of acetyl chloride $(3.36 \mathrm{~mL}, 47.1$ $\mathrm{mmol})$ in $\mathrm{Et}_{2} \mathrm{O}(10 \mathrm{~mL})$ dropwise via syringe at such a rate as to maintain the temperature below $-5^{\circ} \mathrm{C}$. The reaction mixture was warmed to ambient temperature over $1.5 \mathrm{~h}$ and was stirred for an additional $6 \mathrm{~h}$ during which time a brown precipitate formed. The reaction was quenched with water $(50 \mathrm{~mL})$ and was extracted with $\mathrm{Et}_{2} \mathrm{O}(3 \times 30 \mathrm{~mL})$. The combined organic layers were dried $\left(\mathrm{MgSO}_{4}\right)$ and concentrated in vacuo. Purification by flash chromatography (ethyl acetate:hexane, 9:1) provided the title compound as a clear colorless oil $(3.2 \mathrm{~g}, 25 \mathrm{mmol}, 79 \%) . R_{f}$ (ethyl acetate:hexane, 2:3) $0.5 ;{ }^{1} \mathrm{H}$ NMR (250 MHz, $\left.\mathrm{CDCl}_{3}\right) \delta 9.46(\mathrm{~s}, 1 \mathrm{H}), 8.01(\mathrm{q}, J=1.3 \mathrm{~Hz}, 1 \mathrm{H}), 2.29(\mathrm{~s}, 3 \mathrm{H}), 1.77(\mathrm{~d}, J=1.3 \mathrm{~Hz}$, 3H); IR $\left(\mathrm{CHCl}_{3}\right) 1743 \mathrm{~cm}^{-1}$.

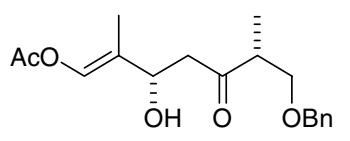

35

$(E), 3(S), 6(R)$-1-Acetoxy-7-benzyloxy-3-hydroxy-2,6-dimethyl-6-hept-1-ene-3-one $35 . \quad$ To a cooled $\left(0{ }^{\circ} \mathrm{C}\right)$ solution of $(+)-\mathrm{Ipc}_{2} \mathrm{BCl}(1.94 \mathrm{~g}, 6.04 \mathrm{mmol})$ in $\mathrm{Et}_{2} \mathrm{O}$ was added $\mathrm{Et}_{3} \mathrm{~N}(0.88 \mathrm{~mL}, 6.31$ mmol) followed by a solution of ketone $26(0.74 \mathrm{~g}, 4.15 \mathrm{mmol})$ dissolved in $\mathrm{Et}_{2} \mathrm{O}(5.0 \mathrm{~mL})$. The resultant white suspension was stirred at this temperature for $2.5 \mathrm{~h}$. The mixture was then cooled to - 
$78{ }^{\circ} \mathrm{C}$ and a solution of the aldehyde 34 (1.09 $\left.\mathrm{g}, 8.50 \mathrm{mmol}, 2.05\right)$ was added slowly via cannula as a solution in $\mathrm{Et}_{2} \mathrm{O}(4.0 \mathrm{~mL}, 3.0 \mathrm{~mL}$ rinse) upon which the suspension turned light yellow. After stirring for 20 min the solution was transferred to a freezer where it was stored for $17 \mathrm{~h}$ at $-20^{\circ} \mathrm{C}$. The mixture was then stirred at $0{ }^{\circ} \mathrm{C}$ for $40 \mathrm{~min}$. The reaction was quenched with a solution of $\mathrm{MeOH}(90 \mathrm{~mL}), \mathrm{pH}$ 7 buffer $(35 \mathrm{~mL})$ and $\mathrm{H}_{2} \mathrm{O}_{2}(100 \mathrm{v} / \mathrm{v}, 9.0 \mathrm{~mL})$, and the biphasic system was stirred vigorously at $0{ }^{\circ} \mathrm{C}$ for $10 \mathrm{~min}$ then at ambient temperature for $1 \mathrm{~h}$. The mixture was poured into water $(80 \mathrm{~mL})$ and was extracted with 1:1 EtOAc:hexane $(1 \mathrm{~L})$. The aqueous layer was re-extracted with the same solvent mixture $(2 \times 100 \mathrm{~mL})$. The combined organic layers were washed with water $(100 \mathrm{~mL})$, dried $\left(\mathrm{MgSO}_{4}\right)$ and evaporated in vacuo. Purification by flash chromatography (ethyl acetate:hexane, 1;9 to 3:7) furnished the product $35(0.85 \mathrm{~g}, 2.78 \mathrm{mmol}, 69 \%)$ as a colorless oil; $R_{f}$ (EtOAc:hexane, 6:4) $0.48 ;[\alpha]_{\mathrm{D}}^{21}-38.1\left(c 0.8, \mathrm{CHCl}_{3}\right) ;{ }^{1} \mathrm{H} \mathrm{NMR}\left(250 \mathrm{MHz}, \mathrm{CDCl}_{3}\right) \delta$ 7.37-7.24 (m, 5H), 7.21 (br s, $\left.1 \mathrm{H}\right)$ 4.55 (br d, $J=8.8 \mathrm{~Hz}, 1 \mathrm{H}), 4.48(\mathrm{~s}, 2 \mathrm{H}), 3.61(\mathrm{~m}, 1 \mathrm{H}), 3.50(\mathrm{~m}, 1 \mathrm{H}), 3.19$ (br s, 1H), 2.93-2.86 (m, 1H), $2.78(\mathrm{dd}, J=17.3,9.2 \mathrm{~Hz}, 1 \mathrm{H}), 2.70(\mathrm{dd}, J=17.3,3.0 \mathrm{~Hz}, 1 \mathrm{H}), 2.15(1 \mathrm{H}, \mathrm{s}), 1.65(\mathrm{~s}, 3 \mathrm{H}), 1.08$ $(\mathrm{d}, J=6.9 \mathrm{~Hz}) ;{ }^{13} \mathrm{C}$ NMR $\left(100 \mathrm{MHz}, \mathrm{CDCl}_{3}\right) \delta 213.5,168.0,137.8,132.3,128.4,127.8,127.7,122.1$, 73.3, 72.1, 68.8, 47.4, 46.9, 20.7, 13.1, 9.9; IR $\left(\mathrm{CHCl}_{3}\right) 3604,1748,1706,1601 \mathrm{~cm}^{-1}$; MS (CI) m/z (rel intensity) 303 [53, (M+H-H $\left.{ }_{2} \mathrm{O}\right)$ ], 83 (100); HRMS (CI) m/z 303.1596 (303.1597 calcd for $\mathrm{C}_{18} \mathrm{H}_{23} \mathrm{O}_{4}$, $\left.\mathrm{M}+\mathrm{H}-\mathrm{H}_{2} \mathrm{O}\right)$.

\section{Proof of Stereochemistry at C3 of 35}

The corresponding $(R)$ and $(S)$ Mosher esters of $\mathbf{3 5}$ were prepared. Relevant ${ }^{1} \mathrm{H}$ NMR data is shown in Figure 1.

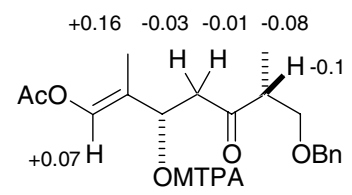

Figure 1. $\Delta \delta\left(\delta_{S}-\delta_{R}\right)$ values (in ppm) for the $(R)$ and $(S)$ Mosher esters prepared from 35. According to the Kakisawa model ${ }^{8}$ the absolute stereochemistry of C3 in $\mathbf{3 5}$ is therefore $(S)$. 


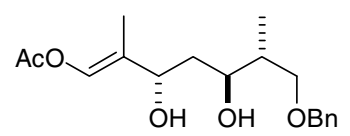

36

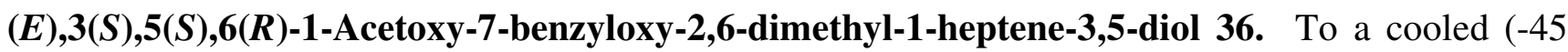
$\left.{ }^{\circ} \mathrm{C}\right)$ solution of $\mathrm{Me}_{4} \mathrm{NBH}(\mathrm{OAc})_{3}(6.7 \mathrm{~g}, 25.5 \mathrm{mmol})$ in dry acetonitrile $(100 \mathrm{~mL})$ and dry acetic acid (16.3 $\mathrm{mL})$ was added a cooled solution of the $\beta$-hydroxy ketone $\mathbf{3 5}$ (2.3 g, $7.18 \mathrm{mmol})$ via cannula as a solution in acetonitrile $\left(20.0 \mathrm{~mL}, 5.0 \mathrm{~mL}\right.$ rinse). The mixture was stirred at $-30{ }^{\circ} \mathrm{C}$ for $36 \mathrm{~h}$ and the reaction was then quenched with saturated aqueous sodium potassium tartrate $(80 \mathrm{~mL})$, and allowed to warm to ambient temperature at which it was stirred for $30 \mathrm{~min}$. The mixture was poured over ice and adjusted to $\mathrm{pH} 9$ with saturated aqueous $\mathrm{NaHCO}_{3}$, and was extracted with EtOAc (400 mL). The aqueous layer was saturated with $\mathrm{NaCl}$ and was extracted with EtOAc $(3 \times 200 \mathrm{~mL})$. The combined organic layers were washed with $\mathrm{NaHCO}_{3}(3 \times 100 \mathrm{~mL})$, dried $\left(\mathrm{MgSO}_{4}\right)$ and evaporated in vacuo affording the title compound $\mathbf{3 6}(2.27 \mathrm{~g}, 7.04 \mathrm{mmol}, 98 \%)$. The unstable diol was stored in solution in toluene at $-20{ }^{\circ} \mathrm{C}$ and was used without purification; $R_{f}$ (EtOAc in hexane, $\left.3: 10\right) 0.28 ;[\alpha]_{\mathrm{D}}^{21}-15.8(c$ 1.9, $\left.\mathrm{CHCl}_{3}\right) ;{ }^{1} \mathrm{H} \mathrm{NMR}\left(250 \mathrm{MHz}, \mathrm{CDCl}_{3}\right) \delta$ 7.38-7.23 (m, 6H), $4.52(\mathrm{~s}, 2 \mathrm{H}), 4.41(\mathrm{dd}, J=8.7,2.3 \mathrm{~Hz}$, $1 \mathrm{H}), 4.10-3.92(\mathrm{br} \mathrm{s}, 1 \mathrm{H}), 3.82(\mathrm{td}, J=7.9,3.0 \mathrm{~Hz}, 1 \mathrm{H}), 3.63(\mathrm{dd}, J=9.2,4.1 \mathrm{~Hz}, 1 \mathrm{H}), 3.48(\mathrm{dd}, J=$ 9.2, 8.2 Hz, 1H), 3.34 (br s, 1H), 2.15 (s, 3H), 2.02-1.93 (m, 1H), 1.85 (ddd, $J=14.3,8.7,3.0 \mathrm{~Hz}, 1 \mathrm{H}$ ), $1.70-1.62(\mathrm{ddd}, J=14.3,7.9,2.3 \mathrm{~Hz}, 1 \mathrm{H}), 1.68(\mathrm{~d}, J=1.2 \mathrm{~Hz}, 3 \mathrm{H}), 0.86(\mathrm{~d}, J=7.0 \mathrm{~Hz}, 3 \mathrm{H}) ;{ }^{13} \mathrm{C} \mathrm{NMR}$ $\left(62.5 \mathrm{MHz}, \mathrm{CDCl}_{3}\right) \delta 168.1,137.5,131.8,128.5,127.9,127.7,123.9,75.6,74.5,73.6,70.3,38.4$, 37.8, 20.8, 13.7, 10.1; IR $\left(\mathrm{CHCl}_{3}\right) 3466,1747,1601 \mathrm{~cm}^{-1}$; MS (CI, $\left.\mathrm{NH}_{3}\right) \mathrm{m} / z$ (rel intensity) 340 [25, (M $\left.\left.+\mathrm{NH}_{4}\right)^{+}\right], 245(100) ; \mathrm{HRMS}\left(\mathrm{CI}, \mathrm{NH}_{3}\right) \mathrm{m} / z \quad 340.2124$ (340.2125 calcd for $\left.\mathrm{C}_{18} \mathrm{H}_{30} \mathrm{NO}_{5}, \mathrm{MNH}_{4}\right)$.

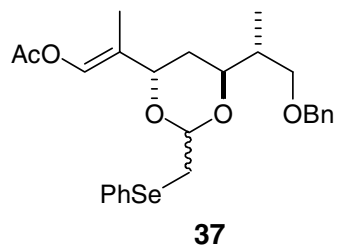




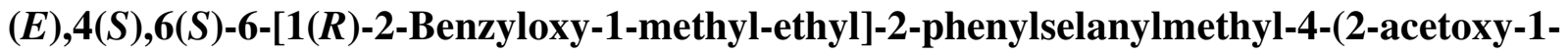

methylvinyl)-[1,3]dioxane 37. A solution of 36 (396 mg, $1.23 \mathrm{mmol}$ ), phenylselenoacetaldehyde diethylacetal $16(553 \mathrm{mg}, 2.02 \mathrm{mmol})$ and PPTS (43 mg, $0.171 \mathrm{mmol})$ in toluene (15 mL) with freshly dried crushed $4 \AA$ molecular sieves was heated at reflux for $48 \mathrm{~h}$. Additional phenylselenoacetaldehyde diethylacetal $16(100 \mathrm{mg}, 0.366 \mathrm{mmol})$ was added and the reaction mixture was heated at reflux for a further $14 \mathrm{~h}$. The cooled mixture was filtered and diluted with EtOAc (100 $\mathrm{mL})$. The solution was washed sequentially with water $(50 \mathrm{~mL})$ then with saturated aqueous $\mathrm{NaHCO}_{3}$ $(50 \mathrm{~mL})$. The organic layer was dried $\left(\mathrm{MgSO}_{4}\right)$ and concentrated in vacuo. The residue was purified by flash chromatography (ethyl acetate:hexane, 4:96 then 5:95) to give the title compound $\mathbf{3 7}$ as a mixture of 2 diastereomers $(345 \mathrm{mg}, 0.686 \mathrm{mmol}, 56 \%)$ as a light yellow oil; $R_{f}$ (ethyl acetate:hexane, 1:4) $0.44 ;[\alpha]_{\mathrm{D}}^{22}+17.4\left(c 1.17, \mathrm{CHCl}_{3}\right) ;{ }^{1} \mathrm{H} \mathrm{NMR}\left(250 \mathrm{MHz}, \mathrm{CDCl}_{3}\right) \delta$ (mixture of 2 diastereomers) 7.52-7.47 (m, 2H), 7.36-7.21 (m, 8H), $7.10(\mathrm{~s}, 1 \mathrm{H}), 5.06(\mathrm{t}, J=5.0 \mathrm{~Hz}, 0.5 \mathrm{H}), 4.89(\mathrm{t}, J=5.0 \mathrm{~Hz}, 1 \mathrm{H})$, 4.60-4.42 (m, 2H), 4.23-4.18 (m, 1H), 3.94-3.79 (m, 1H), 3.71-3.66 (m, 0.5H), 3.49-3.33 (m, 1.5H), 3.11-3.01 (m, 2H), 2.52-2.38 (m, 1H), $2.17(\mathrm{~s}, 1.5 \mathrm{H}), 2.15(\mathrm{~s}, 1.5 \mathrm{H}), 2.11-1.83(\mathrm{~m}, 2 \mathrm{H}), 1.73,(\mathrm{~s}, 1.5 \mathrm{H})$, $1.71(\mathrm{~s}, 1.5 \mathrm{H}), 0.90-0.82(\mathrm{~m}, 3 \mathrm{H}) ; \mathrm{IR}\left(\mathrm{CHCl}_{3}\right) 1749 \mathrm{~cm}^{-1} ;{ }^{13} \mathrm{C} \mathrm{NMR}\left(100 \mathrm{MHz}, \mathrm{CDCl}_{3}\right) \delta 168.0,138.7$, $133.7,132.6,132.1,132.0,130.7,129.0,128.3,127.6,127.5,127.4,126.7,126.6,121.1,121.0,95.4$, $94.9,74.2,73.9,73.3,73.1,73.0,72.0,71.4,38.5,32.2,31.7,31.6,29.3,27.8,20.8,14.7,12.6,12.1$, 10.1; $\mathrm{MS}\left(\mathrm{CI}, \mathrm{NH}_{3}\right) \mathrm{m} / z$ (rel intensity) $522\left[22,\left(\mathrm{M}+\mathrm{NH}_{4}\right)^{+}\right] ; \mathrm{HRMS}\left(\mathrm{CI}, \mathrm{NH}_{3}\right) \mathrm{m} / z \quad 522.1760$ (522.1760 calcd for $\mathrm{C}_{26} \mathrm{H}_{36} \mathrm{O}_{5} \mathrm{Se}, \mathrm{MNH}_{4}$ ).

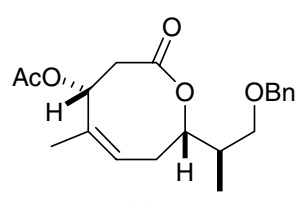

38

$(Z), 4(R), 8(S)-4-A c e t o x y-8-[1(R)-2-b e n z y l o x y-1-m e t h y l-e t h y l]-5-m e t h y l-3,4,7,8-t e t r a h y d r o-2 H-$

oxocin-2-one 38. A mixture of acetals $37(250 \mathrm{mg}, 0.496 \mathrm{mmol}), \mathrm{NaIO}_{4}(414 \mathrm{mg}, 1.93 \mathrm{mmol})$ and $\mathrm{NaHCO}_{3}(204 \mathrm{mg}, 2.43 \mathrm{mmol})$ in EtOAc $(4 \mathrm{~mL})$, methanol $(8 \mathrm{~mL})$ and water $(1.5 \mathrm{~mL})$ was stirred 
vigorously at $22{ }^{\circ} \mathrm{C}$ for $1.5 \mathrm{~h}$. The reaction mixture was poured into water $(50 \mathrm{~mL})$ and was extracted with EtOAc $(100 \mathrm{~mL})$. The aqueous layer was saturated with $\mathrm{NaCl}$ and extracted again with EtOAc (2 $\times 100 \mathrm{~mL})$. The combined organic layers were dried $\left(\mathrm{MgSO}_{4}\right)$ and concentrated in vacuo to give a quantitative yield of the selenoxide (262 mg) which was used in the next step without purification.

A solution of the above selenoxide $(262 \mathrm{mg}, 0.496 \mathrm{mmol})$ and 1-tert-butyldimethylsiloxy-1-methoxy ethene $18(1.17 \mathrm{~g}, 6.19 \mathrm{mmol})$ in dry xylene $(30 \mathrm{~mL})$ with $\mathrm{K}_{2} \mathrm{CO}_{3}(362 \mathrm{mg}, 2.62 \mathrm{mmol})$ was heated in a sealed tube at $180{ }^{\circ} \mathrm{C}$ for $2.5 \mathrm{~h}$. The mixture was cooled then washed with saturated aqueous $\mathrm{NH}_{4} \mathrm{Cl}$ (100 mL). The xylene was removed under high vacuum, and the residue was purified by flash chromatography (ethyl acetate:hexane, 1:9) to give the title compound 38 (68 mg, $0.196 \mathrm{mmol}, 40 \%$ ) as a clear oil. Also recovered was the selenide 37 (60.5 mg, $0.120 \mathrm{mmol}, 24 \%)$. Data for 38; $R_{f}$ (ethyl acetate:hexane, 1:4) 0.25; $[\alpha]_{\mathrm{D}}^{21}-12.8\left(c, 2.18, \mathrm{CHCl}_{3}\right) ;{ }^{1} \mathrm{H}$ NMR $\left(400 \mathrm{MHz}, \mathrm{CDCl}_{3}\right) \delta$ 7.37-7.27 (m, $5 \mathrm{H}), 5.65(\mathrm{t}, J=7.2 \mathrm{~Hz}, 1 \mathrm{H}), 5.42(\mathrm{t}, J=6.7 \mathrm{~Hz}, 1 \mathrm{H}), 4.66(\mathrm{q}, J=7.5 \mathrm{~Hz}, 1 \mathrm{H}), 4.47$ (s, 2H), 3.48 (dd, $J 5.5,9.1 \mathrm{~Hz}, 1 \mathrm{H}) 3.44(\mathrm{dd}, J=4.4,9.1 \mathrm{~Hz}, 1 \mathrm{H}), 3.10(\mathrm{dd}, J=14.3,7.2 \mathrm{~Hz}, 1 \mathrm{H}), 2.87(\mathrm{dd}, J=14.3$, $7.2 \mathrm{~Hz}, 1 \mathrm{H}), 2.39(\mathrm{dd}, J=6.8,7.2 \mathrm{~Hz}, 2 \mathrm{H}), 2.03(\mathrm{~s}, 3 \mathrm{H}), 2.02-1.97(\mathrm{~m}, 1 \mathrm{H}), 1.72(\mathrm{~s}, 3 \mathrm{H}), 1.02(\mathrm{~d}, J=$ 8.0 Hz, 3H); $\left.{ }^{13} \mathrm{C} \mathrm{NMR} \mathrm{(100} \mathrm{MHz,} \mathrm{CDCl}_{3}\right) \delta 172.4,170.0,138.4,137.7,128.4,127.6,121.8,79.5$, 73.2, 71.6, 70.1, 42.3, 38.5, 31.1, 20.9, 20.0, 13.7; IR $\left(\mathrm{CHCl}_{3}\right) 1734 \mathrm{~cm}^{-1} ; \mathrm{MS}(\mathrm{CI}, \mathrm{NH}) \mathrm{m} / z(\mathrm{rel}$ intensity) $347\left[36,(\mathrm{M}+\mathrm{H})^{+}\right]$.

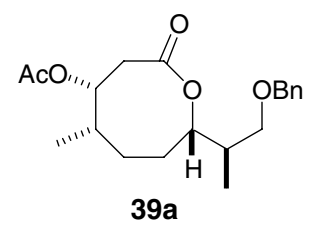

4(R),5(S),8(S)-4-Acetoxy-8-[1(R)-benzyloxy-1-methyl-ethyl]-5-methyl-oxocan-2-one 39a. To a solution of the lactone $38(35 \mathrm{mg}, 100 \mu \mathrm{mmol})$ in EtOAc $(2 \mathrm{~mL})$ was added $\mathrm{PtO}_{2}$ and the mixture was stirred vigorously under an atmosphere of $\mathrm{H}_{2}$ for $10 \mathrm{~h}$. The mixture was filtered through Celite followed by concentration in vacuo provided the title compound 39a; $R f$ (hexane:ethyl acetate, 4:1) 
0.14; ${ }^{1} \mathrm{H}$ NMR $\left(500 \mathrm{MHz}, \mathrm{CDCl}_{3}\right.$ major diastereomer) $\delta$ 7.37-7.27 (m, 5H), 5.00 (br d, $\left.J=6.2 \mathrm{~Hz}, 1 \mathrm{H}\right)$, 4.47-4.40 (m, 3H), 3.61 (dd, $J=9.0,4.4 \mathrm{~Hz}, 1 \mathrm{H}), 3.37(\mathrm{dd}, J=9.0,4.4 \mathrm{~Hz}, 1 \mathrm{H}), 2.89(\mathrm{dd}, J=13.5,6.2$ $\mathrm{Hz}, 1 \mathrm{H}), 2.73(\mathrm{dd}, J=13.5,1.8 \mathrm{~Hz}, 1 \mathrm{H}), 2.10(\mathrm{~s}, 3 \mathrm{H}), 2.09-1.90(\mathrm{~m}, 1 \mathrm{H}), 1.88-1.91(\mathrm{~m}, 2 \mathrm{H}), 1.77-1.71$ (m, 1H), 1.70-1.65 (m, 3H), $1.02(\mathrm{~d}, J 7.1 \mathrm{~Hz}, 6 \mathrm{H})$.

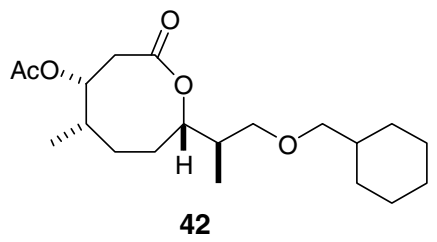

4(R),5(S),8(S)-4-Acetoxy-8-[1(R)-2-cyclohexylmethoxy-1-methyl-ethyl]-5-methyl-3,4,7,8-

tetrahydro-oxocin-2-one 42. $R_{f}($ EtOAc in hexane, $1: 4) 0.28 ;{ }^{1} \mathrm{H}$ NMR $\left(200 \mathrm{MHz}, \mathrm{CDCl}_{3}\right) \delta 5.03(\mathrm{~d}, J$ $5.8 \mathrm{~Hz}, 1 \mathrm{H}), 4.43(\mathrm{~m}, 1 \mathrm{H}), 3.54-3.21(\mathrm{~m}, 2 \mathrm{H}), 3.15(\mathrm{~d}, J 6.4 \mathrm{~Hz}, 2 \mathrm{H}), 2.10(\mathrm{~s}, 3 \mathrm{H}), 1.99-1.51(\mathrm{~m}, 11 \mathrm{H})$, $1.48-1.15(\mathrm{~m}, 4 \mathrm{H}), 1.09-0.85(\mathrm{~m}, 8 \mathrm{H})$.

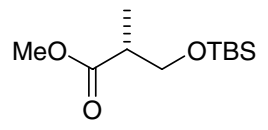

Methyl-(R)-3-(tert-butyldimethylsiloxy)-2-methyl-propionate. ${ }^{9} \quad$ To a solution of methyl-(R)-3hydroxy-2-methyl-propionate $(10.3 \mathrm{~g}, 87.2 \mathrm{mmol})$ in $\mathrm{CH}_{2} \mathrm{Cl}_{2}(100 \mathrm{~mL})$ at $0{ }^{\circ} \mathrm{C}$ was added imidazole (9.9 g, $145 \mathrm{mmol})$ and DMAP (106 mg, $0.87 \mathrm{mmol})$. A solution of TBSCl (16.6 g, $110 \mathrm{mmol})$ in $\mathrm{CH}_{2} \mathrm{Cl}_{2}(25 \mathrm{~mL})$ was added dropwise via syringe. After the addition the cooling bath was removed and the mixture was stirred at ambient temperature for $40 \mathrm{~min}$. The reaction mixture was quenched by the addition of saturated aqueous $\mathrm{NH}_{4} \mathrm{Cl}(120 \mathrm{~mL})$, followed by water $(50 \mathrm{~mL})$. The aqueous layer was extracted with $\mathrm{Et}_{2} \mathrm{O}(4 \times 60 \mathrm{~mL})$. The combined organic extracts were dried $\left(\mathrm{MgSO}_{4}\right)$ and evaporated in vacuo. Purification by flash column chromatography (hexane:ether, 40:1, 20:1 and finally 10:1) afforded the title compound (19.9 $\mathrm{g}, 87 \mathrm{mmol}, 98 \%)$ as a clear colorless oil; $R_{f}$ (hexane:ether, 9:1) $0.31 ;[\alpha]_{\mathrm{D}}^{20}-18.2\left(c 0.89, \mathrm{CHCl}_{3}\right),\left\{\right.$ lit. $^{9}[\alpha]_{\mathrm{D}}^{24}-18.4\left(c\right.$ 2.02, $\left.\left.\mathrm{CHCl}_{3}\right)\right\} ;{ }^{1} \mathrm{H} \mathrm{NMR}\left(400 \mathrm{MHz}, \mathrm{CDCl}_{3}\right) \delta$ $3.79(\mathrm{dd}, J=9.7,6.8 \mathrm{~Hz}, 1 \mathrm{H}), 3.65(\mathrm{~s}, 3 \mathrm{H}), 3.65-3.61(\mathrm{dd}, J=9.7,6.8 \mathrm{~Hz}, 1 \mathrm{H}), 2.67-2.59(\mathrm{~m}, 1 \mathrm{H})$, 
$1.12(\mathrm{~d}, J=7.1 \mathrm{~Hz}, 3 \mathrm{H}), 0.86(\mathrm{~s}, 9 \mathrm{H}), 0.12(\mathrm{~d}, J=1.4 \mathrm{~Hz}, 6 \mathrm{H}) ;{ }^{13} \mathrm{C} \mathrm{NMR}\left(100 \mathrm{MHz}, \mathrm{CDCl}_{3}\right) \delta 175.4$ 65.2, 51.4, 42.5, 25.718 .2 13.4, -5.6; IR $\left(\mathrm{CDCl}_{3}\right) 1733 \mathrm{~cm}^{-1} ; \mathrm{MS}\left(\mathrm{CI}, \mathrm{NH}_{3}\right) \mathrm{m} / z$ (rel intensity) 233 [45, $\left.(\mathrm{M}+\mathrm{H})^{+}\right] . \quad \mathrm{HRMS}(\mathrm{Q}-\mathrm{TOF}) \mathrm{m} / z 255.1392$ (255.1392 calcd for $\left.\mathrm{C}_{11} \mathrm{H}_{24} \mathrm{O}_{3} \mathrm{SiNa}, \mathrm{MNa}\right)$.

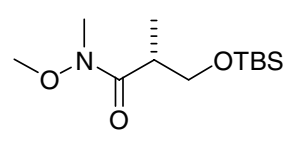

(R)-3-(tert-Butyldimethylsiloxy)- $N$-methoxy-2, $N$-dimethylpropanamide. A solution of methyl(R)-3-(tert-butyldimethylsiloxy)-2-methyl-propionate $\quad(19.7 \quad \mathrm{~g}, \quad 84.7 \quad \mathrm{mmol}) \quad$ and $\quad N, O-$ dimethylhydroxylamine hydrochloride $(10.5 \mathrm{~g}, 107.5 \mathrm{mmol})$ in $\mathrm{THF}(220 \mathrm{~mL})$ was cooled to $-10{ }^{\circ} \mathrm{C}$ using an ice-salt bath. Isopropylmagnesium bromide (107 mL, 2.0 M in $\left.\mathrm{Et}_{2} \mathrm{O}\right)$ was added dropwise, maintaining the temperature below $-5{ }^{\circ} \mathrm{C}$ (addition time $40 \mathrm{~min}$ ). The mixture was stirred at $-10{ }^{\circ} \mathrm{C}$ for $30 \mathrm{~min}$ and was quenched by the addition of saturated $\mathrm{NH}_{4} \mathrm{Cl}$ solution $(150 \mathrm{~mL})$. After the addition of $\mathrm{H}_{2} \mathrm{O}(150 \mathrm{~mL})$, the mixture was extracted with $\mathrm{Et}_{2} \mathrm{O}(4 \times 100 \mathrm{~mL})$. The combined organic extracts were dried $\left(\mathrm{MgSO}_{4}\right)$ and evaporated in vacuo. Purification by flash chromatography (EtOAc) through a short plug of silica yielded the title compound as a colorless oil $(21.5 \mathrm{~g}, 82.2 \mathrm{mmol}, 97 \%) . \quad R_{f}$ (hexane:ether, 9:1) 0.06; $[\alpha]_{\mathrm{D}}^{20}-17.1\left(c 0.795 . \mathrm{CHCl}_{3}\right),\left\{\right.$ lit. enantiomer $\left.{ }^{10}[\alpha]_{\mathrm{D}}^{24}+24.4\left(c 1.0, \mathrm{CHCl}_{3}\right)\right\} ;{ }^{1} \mathrm{H}$ $\operatorname{NMR}\left(250 \mathrm{MHz}, \mathrm{CDCl}_{3}\right) \delta 3.80(\mathrm{dd}, J=9.7,6.8 \mathrm{~Hz}, 1 \mathrm{H}), 3.68(\mathrm{~s}, 3 \mathrm{H}), 3.50(\mathrm{dd}, J=9.7,6.8 \mathrm{~Hz}$, $1 \mathrm{H}), 3.15(\mathrm{~s}, 3 \mathrm{H}), 1.05(\mathrm{~d}, J=6.8 \mathrm{~Hz}, 3 \mathrm{H}), 0.85(\mathrm{~s}, 9 \mathrm{H}), 0.01(\mathrm{~s}, 6 \mathrm{H}) ;{ }^{13} \mathrm{C} \mathrm{NMR}\left(62.5 \mathrm{MHz}, \mathrm{CDCl}_{3}\right)$ $\delta 175.9,65.7,61.4,38.1,32.1,25.8,18.2,13.7,-5.5 ; \mathrm{IR}\left(\mathrm{CDCl}_{3}\right) 1650 \mathrm{~cm}^{-1} ; \mathrm{HRMS}(\mathrm{Q}-\mathrm{TOF}) \mathrm{m} / z$ 284.1686 (284.1658 calcd for $\mathrm{C}_{12} \mathrm{H}_{27} \mathrm{O}_{3} \mathrm{SiNa}, \mathrm{MNa}$ ).

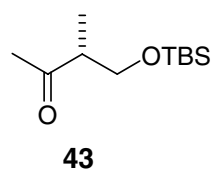

(R)-4-(tert-Butyldimethylsilyloxy)-3-methyl-butan-2-one 43. To a solution of the (R)-3-(tertbutyldimethylsiloxy)- $N$-methoxy-2,N-dimethylproanamide (12.7 g, $48.7 \mathrm{mmol})$ in $\mathrm{THF}(150 \mathrm{ml})$ 
cooled to $0{ }^{\circ} \mathrm{C}$ was added methylmagnesium bromide $(27.6 \mathrm{ml}, 2.0 \mathrm{M}$ in ether, $82.7 \mathrm{mmol})$ dropwise

via syringe. After 40 min the reaction was quenched with aqueous $\mathrm{NH}_{4} \mathrm{Cl}(150 \mathrm{~mL})$ and the mixture was allowed to warm to ambient temperature. The resultant suspension was extracted with $\mathrm{Et}_{2} \mathrm{O}(3 \times$ $150 \mathrm{~mL})$. The combined organic extracts were washed with brine $(150 \mathrm{~mL})$, dried $\left(\mathrm{Na}_{2} \mathrm{SO}_{4}\right)$ and concentrated in vacuo. Purification by flash chromatography (ethyl acetate:hexane, 3:1) yielded the title compound $(10.3 \mathrm{~g}, 48.0 \mathrm{mmol}, 98 \%)$ as a clear colorless oil. $R_{f}$ (hexane:ether, $\left.3: 1\right) 0.56 ;[\alpha]_{\mathrm{D}}^{20}$ $29.1\left(c 0.87, \mathrm{CHCl}_{3}\right),\left\{\right.$ lit. enantiomer ${ }^{10}[\alpha]_{\mathrm{D}}^{20}+33.5\left(c\right.$ 1.0, $\left.\left.\mathrm{CHCl}_{3}\right)\right\} ;{ }^{1} \mathrm{H} \mathrm{NMR}\left(250 \mathrm{MHz}, \mathrm{CDCl}_{3}\right) \delta$ $3.65(\mathrm{~m}, 2 \mathrm{H}), 2.68(\mathrm{~m}, 1 \mathrm{H}), 2.15(\mathrm{~s}, 3 \mathrm{H}), 1.01(\mathrm{~d}, J=7.0 \mathrm{~Hz}, 3 \mathrm{H}), 0.84(\mathrm{~s}, 9 \mathrm{H}), 0.01(\mathrm{~s}, 3 \mathrm{H}), 0.00(\mathrm{~s}$, $3 \mathrm{H}) ;{ }^{13} \mathrm{C} \mathrm{NMR}\left(62.5 \mathrm{MHz}, \mathrm{CDCl}_{3}\right) \delta 211.6,65.4,49.3,29.4,25.8,18.1,12.8,-5.6$; IR $\left(\mathrm{CHCl}_{3}\right) 1711$ $\mathrm{cm}^{-1}$; Anal. Calcd for $\mathrm{C}_{11} \mathrm{H}_{24} \mathrm{O}_{2} \mathrm{Si}: \mathrm{C}, 61.1 ; \mathrm{H}, 11.2$. Found: C, 61.1; H, 11.1. HRMS (Q-TOF) $\mathrm{m} / z$ 239.1459 (239.1443 calcd for $\mathrm{C}_{11} \mathrm{H}_{24} \mathrm{O}_{2} \mathrm{SiNa}, \mathrm{MNa}$ ).

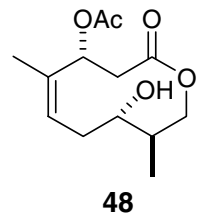

$5(Z), 4(R), 8(S), 9(S)$-4-Acetoxy-5,9-dimethyl-8-hydroxy-3,4,7,8,9,10-hexahydro-oxecin-2-one

48.

To a solution of the lactone $47(11.0 \mathrm{mg}, 0.031 \mathrm{mmol})$ in $\mathrm{THF}(550 \mu \mathrm{L})$ and pyridine $(250 \mu \mathrm{L})$ at $0{ }^{\circ} \mathrm{C}$ was added $70 \% \mathrm{HF} /$ pyridine $(100 \mu \mathrm{L})$. The cooling bath was removed and the reaction was stirred at ambient temperature for $24 \mathrm{~h}$. Filtration of the reaction mixture through silica gave the title compound $48(7.4 \mathrm{mg}, 0.029 \mathrm{mmol}, 94 \%)$ as colorless needles; mp $117{ }^{\circ} \mathrm{C}$ (ether); $[\alpha]_{\mathrm{D}}^{22}+30.6\left(c 0.81, \mathrm{CHCl}_{3}\right)$; ${ }^{1} \mathrm{H}$ NMR $\left(400 \mathrm{MHz}, \mathrm{CDCl}_{3}\right) \delta 6.08(\mathrm{dd}, J=11.4,5.8 \mathrm{~Hz}, 1 \mathrm{H}), 5.22(\mathrm{~d}, J=12.4 \mathrm{~Hz}, 1 \mathrm{H}), 4.36(\mathrm{dd}, J=$ 11.1, $2.4 \mathrm{~Hz}, 1 \mathrm{H}), 3.90(\mathrm{t}, J=11.1 \mathrm{~Hz}, 1 \mathrm{H}), 3.77(\mathrm{~m}, 1 \mathrm{H}), 2.98-2.88(\mathrm{~m}, 2 \mathrm{H}), 2.52(\mathrm{dd}, J=13.6,11.5$ $\mathrm{Hz}, 1 \mathrm{H}), 2.35-2.30(\mathrm{~m}, 1 \mathrm{H}), 2.05(\mathrm{~s}, 3 \mathrm{H}), 2.00-1.96(\mathrm{~m}, 1 \mathrm{H}), 1.70(\mathrm{~s}, 3 \mathrm{H}), 1.58(\mathrm{~s}, 1 \mathrm{H}), 0.92(\mathrm{~d}, J=7.2$ $\mathrm{Hz}, 3 \mathrm{H}) ;{ }^{13} \mathrm{C} \mathrm{NMR}\left(100 \mathrm{MHz}, \mathrm{CDCl}_{3}\right) \delta 170.0,168.6,132.7,125.4,73.7,68.6,37.7,36.0,33.9,21.0$, 
17.4, 14.7; IR $\left(\mathrm{CHCl}_{3}\right)$ 3515, 1738; $\mathrm{MS}\left(\mathrm{CI}, \mathrm{NH}_{3}\right) \mathrm{m} / z$ (rel intensity) $256\left[2,(\mathrm{M}+\mathrm{H})^{+}\right], 274[100,(\mathrm{M}+$ $\left.\left.\mathrm{NH}_{4}\right)^{+}\right]$; HRMS (CI, $\left.\mathrm{NH}_{3}\right) \mathrm{m} / z 274.1654$ (274.1654 calcd for $\left.\mathrm{C}_{13} \mathrm{H}_{24} \mathrm{NO}_{5} \mathrm{MNH}_{4}\right)$.

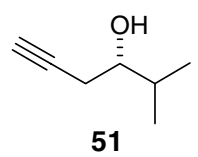

(S)-4-Hydroxy-5-methyl-1-hexyne, 51. Allenylboronic acid 24 (3.4 g, $40.5 \mathrm{mmol})$ and freshly dried crushed $5 \AA$ molecular sieves (15 g) were suspended in dry toluene (80 mL). (+)-Diethyltartrate was added and the mixture was stirred for $24 \mathrm{~h}$ at ambient temperature under a stream of Ar. The solution was decanted via cannula into a dry flask under Ar, and the residue was washed through with toluene $(20 \mathrm{~mL})$. The solution was cooled to $-78{ }^{\circ} \mathrm{C}$ and isobutyraldehyde $(6.0 \mathrm{~mL}, 66.0 \mathrm{mmol})$ was added dropwise via syringe. The mixture was stirred at $-70{ }^{\circ} \mathrm{C}$ for $21 \mathrm{~h}$. The reaction was quenched by the addition of ice cold $1 \mathrm{M} \mathrm{HCl}(120 \mathrm{~mL})$, diluted with $\mathrm{Et}_{2} \mathrm{O}(250 \mathrm{~mL})$ and transferred to a separating funnel. The aqueous layer was washed with $\mathrm{Et}_{2} \mathrm{O}(3 \times 150 \mathrm{~mL})$ (Difficult phase separation was aided by the addition of solid $\mathrm{NaCl})$. The combined organic extracts were dried $\left(\mathrm{MgSO}_{4}\right)$, filtered, and evaporated in vacuo at $-10^{\circ} \mathrm{C}$. The volatile title compound was stored as a solution in toluene; $R_{f}$ (hexane:ethyl acetate 1:5) $0.13 ;[\alpha]_{\mathrm{D}}^{20}+7.1\left(c\right.$ 1.6, $\left.\mathrm{CHCl}_{3}\right) ;{ }^{1} \mathrm{H} \mathrm{NMR}\left(250 \mathrm{MHz}, \mathrm{CDCl}_{3}\right) \delta 3.55-3.44(\mathrm{~m}$, $1 \mathrm{H}), 2.51-2.26(\mathrm{~m}, 2 \mathrm{H}), 2.04(\mathrm{t}, J=2.6 \mathrm{~Hz}, 1 \mathrm{H}), 1.95(\mathrm{~d}, J=4.8 \mathrm{~Hz}, 1 \mathrm{H}), 1.88-1.71(\mathrm{~m}, 1 \mathrm{H}), 0.96(\mathrm{~d}, J$ $=6.8 \mathrm{~Hz}, 3 \mathrm{H}), 0.92(\mathrm{~d}, J=6.8 \mathrm{~Hz}, 3 \mathrm{H}) ;{ }^{13} \mathrm{C}\left(100 \mathrm{MHz}, \mathrm{CDCl}_{3}\right) \delta 81.2,74.7,70.5,32.6,24.6,18.6$, 17.6. IR $\left(\mathrm{CDCl}_{3}\right) 3532,3307 \mathrm{~cm}^{-1}$

\section{Proof of Stereochemistry at C3 of 51}

The corresponding $(R)$ and $(S)$ Mosher esters of 51 were prepared. Relevant ${ }^{1} \mathrm{H}$ NMR data is shown in Figure 2.

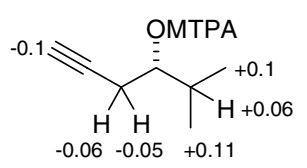


Figure 2. $\Delta \delta\left(\delta_{S}-\delta_{R}\right)$ values for the $(R)$ and $(S)$ Mosher esters prepared from 51. According to the Kakisawa model the absolute stereochemistry of C3 in $\mathbf{5 1}$ is therefore $(S)$.

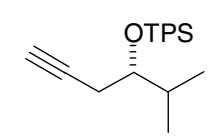

(S)-4-(tert-Butyldiphenylsiloxy)-5-methyl-1-hexyne. A solution of the alcohol 51 (approximately $4.0 \mathrm{~g}, 35 \mathrm{mmol}), t$-butyldimethylsilylchloride $(15.7 \mathrm{~g}, 105 \mathrm{mmol}, 3 \mathrm{eq})$ and imidazole $(14.3 \mathrm{~g}, 210$ mmol, 6 eq) in 1:1 toluene/DMF $(120 \mathrm{~mL})$ was stirred at ambient temperature for 4 days. The mixture was diluted with water $(250 \mathrm{~mL})$ and was extracted with a mixture of EtOAc:hexane 1:1 $(3 \times 100 \mathrm{~mL})$. The combined organic layers were washed with brine and dried $\left(\mathrm{MgSO}_{4}\right)$. Evaporation in vacuo provided the crude product as a viscous oil. Flash chromatography (hexane) afforded the title compound (3.3 g, 14.6 mmol, 35\%, 2 steps); $R_{f}$ (hexane) $0.23 ;[\alpha]_{\mathrm{D}}^{20}+18.1\left(c 14.0, \mathrm{CHCl}_{3} ;{ }^{1} \mathrm{H}\right.$ NMR $\left(250 \mathrm{MHz}, \mathrm{CDCl}_{3}\right) \delta$ 7.75-7.70 (m, 4H), 7.48-7.35 (m, 6H), $3.72(\mathrm{~m}, 1 \mathrm{H}), 2.31-2.26(\mathrm{~m}, 2 \mathrm{H}), 2.18-1.95$ $(\mathrm{m}, 1 \mathrm{H}), 1.87(\mathrm{~m}, 1 \mathrm{H}), 1.10(\mathrm{~s}, 9 \mathrm{H}),, 0.94(\mathrm{~d}, J=2.1 \mathrm{~Hz}), 0.92(\mathrm{~d}, J=2.2 \mathrm{~Hz}) ;{ }^{13} \mathrm{C} \mathrm{NMR}(100 \mathrm{MHz}$ $\left.\mathrm{CDCl}_{3}\right) \delta 136.1,136.0,134.6,133.8,129.6,129.6,129.0,128.2,127.5,127.4,81.7,76.1,69.9,32.2$ 27.1, 24.2, 19.6, 18.9, 16.6; IR $\left(\mathrm{CDCl}_{3}\right) 3308,1261,1101 \mathrm{~cm}^{-1} ; \mathrm{MS}\left(\mathrm{CI}, \mathrm{NH}_{3}\right) \mathrm{m} / z$ (rel intensity) 351 [18, $\left.(\mathrm{M}+\mathrm{H})^{+}\right]$; HRMS (EI) $m / z \quad 351.2144$ (351.2145 calcd for $\left.\mathrm{C}_{23} \mathrm{H}_{31} \mathrm{OSi}, \mathrm{MH}\right)$.

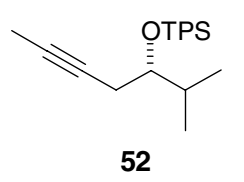

(S)-5-(tert-Butyldiphenylsiloxy)-6-methyl-2-heptyne 52. To a solution of the (S)-4-(tertbutyldiphenylsiloxy)-5-methyl-1-hexyne $(5.0 \mathrm{~g}, 14.26 \mathrm{mmol})$ in dry THF (80 mL) at $-78{ }^{\circ} \mathrm{C}$ was added $n \mathrm{BuLi}(14.0 \mathrm{~mL}, 1.6 \mathrm{M}$ solution in hexane, $22.5 \mathrm{mmol})$ and the mixture was stirred for $25 \mathrm{~min}$. MeI $(1.9 \mathrm{~mL}, 30.1 \mathrm{mmol})$ was added and the mixture was allowed to warm to $0{ }^{\circ} \mathrm{C}$ over $1.5 \mathrm{~h}$. It was then warmed to ambient temperature and stirred for $1 \mathrm{~h}$. Water $(200 \mathrm{~mL})$ was added to the reaction mixture 
followed by $\mathrm{Et}_{2} \mathrm{O}(150 \mathrm{~mL})$. The layers were separated and the aqueous layer was washed with $\mathrm{Et}_{2} \mathrm{O}(2$ $\times 150 \mathrm{~mL})$. The combined organic layers were dried $\left(\mathrm{MgSO}_{4}\right)$ and concentrated. The crude product was passed through a short plug of silica eluting with hexane to give the title compound (6.2 $\mathrm{g}, 14.2$ mmol, 95\%) as a clear oil; $R_{f}$ (hexane) $0.23 ;[\alpha]_{\mathrm{D}}^{20}+20.6\left(c 3.4, \mathrm{CHCl}_{3}\right) ;{ }^{1} \mathrm{H} \mathrm{NMR}\left(400 \mathrm{MHz}, \mathrm{CDCl}_{3}\right)$ $\delta$ 7.79-7.74 (m, 4H), 7.50-7.40 (m, 6H), 3.78-3.74 (td, $J=6.3,3.6 \mathrm{~Hz}, 1 \mathrm{H}), 2.33-2.27(\mathrm{~m}, 2 \mathrm{H}), 2.06-$ $1.98(\mathrm{~m}, 1 \mathrm{H}), 1.70(\mathrm{t}, J=2.5 \mathrm{~Hz}, 3 \mathrm{H}), 1.15(\mathrm{~s}, 9 \mathrm{H}), 0.98(\mathrm{~d}, J=2.0 \mathrm{~Hz}, 3 \mathrm{H}), 0.96(\mathrm{~d}, J=2.0 \mathrm{~Hz}, 3 \mathrm{H})$; ${ }^{13} \mathrm{C} \mathrm{NMR}\left(100 \mathrm{MHz}, \mathrm{CDCl}_{3}\right) \delta 136.1,136.0,134.7,129.5,129.4,127.5,127.3,77.1,76.5,32.2,27.1$, 24.4, 19.6 18.8, 16.5, 3.4; IR $\left(\mathrm{CDCl}_{3}\right) 1472,1428,1111,1064 \mathrm{~cm}^{-1} ; \mathrm{MS}\left(\mathrm{CI}, \mathrm{NH}_{3}\right) \mathrm{m} / z$ (rel intensity) $365\left[(\mathrm{M}+\mathrm{H})^{+}\right]$; HRMS $\left(\mathrm{CI}, \mathrm{NH}_{3}\right) \mathrm{m} / z 365.2295$ (365.2301 calcd for $\left.\mathrm{C}_{24} \mathrm{H}_{33} \mathrm{OSi}, \mathrm{MH}\right)$.

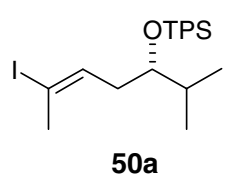

(S)-5-(tert-Butyldiphenylsiloxy)-6-methyl-2-iodo-2-heptene 50a. A dry 3-necked flask was attached to a vacuum manifold and evacuated with heating for $1 \mathrm{~h}$ prior to use. Bis(cyclopentadienyl) zirconium chloride hydride $(4.0 \mathrm{~g}, 15.5 \mathrm{mmol})$ was weighed into a vial in a glove box and was transferred to the flask under a dry Ar stream. To the flask was added THF $(80 \mathrm{~mL})$. The heptyne $\mathbf{5 2}$ (1.4 g, $3.84 \mathrm{mmol})$ was then added via cannula as a solution in THF (5.0 mL, $2.0 \mathrm{~mL}$ rinse). The flask was excluded from light and the mixture was stirred for $4 \mathrm{~h}$. A solution of $\mathrm{I}_{2}(3.9 \mathrm{~g}, 15.4 \mathrm{mmol})$ in THF (20 mL) was added over $5 \mathrm{~min}$. The mixture was stirred for a further $40 \mathrm{~min}$ at ambient temperature. Hexane $(70 \mathrm{~mL})$ was added to the mixture, and the resultant suspension was passed through a plug of silica eluting with hexane. The eluent was concentrated and the crude product was purified by flash chromatography (hexane) to afford the title compound (1.13 $\mathrm{g}, 2.3 \mathrm{mmol}, 60 \%)$ as a 9:1 inseparable mixture of 50a:50b; $R_{f}$ (hexane) $0.34 ;[\alpha]_{\mathrm{D}}^{20}+12.8\left(c 2.4, \mathrm{CHCl}_{3}\right) ;{ }^{1} \mathrm{H} \mathrm{NMR}(400 \mathrm{MHz}$, $\mathrm{CDCl}_{3}$, major diastereomer) $\delta 7.74-7.68(\mathrm{~m}, 4 \mathrm{H}), 7.45-7.36(\mathrm{~m}, 6 \mathrm{H}), 5.98(\mathrm{td}, J=7.5,1.3 \mathrm{~Hz}, 1 \mathrm{H})$, $3.58(\mathrm{td}, J=6.2,3.5 \mathrm{~Hz}, 1 \mathrm{H}), 2.13(\mathrm{~s}, 3 \mathrm{H}), 2.10-2.06(\mathrm{~m}, 2 \mathrm{H}), 1.75-1.67(\mathrm{~m}, 1 \mathrm{H}), 1.07(\mathrm{~s}, 9 \mathrm{H}), 0.92(\mathrm{~d}$, 
$J=6.9 \mathrm{~Hz} 3 \mathrm{H}), 0.84(\mathrm{~d}, J=6.9 \mathrm{~Hz}, 3 \mathrm{H}) ;{ }^{13} \mathrm{C} \mathrm{NMR}\left(100 \mathrm{MHz}, \mathrm{CDCl}_{3}\right) \delta 138.1,136.1,136.1,136.0$, $136.0,134.1,129.6,129.5,127.5,127.5,127.4,94.8,34.5,32.4,27.5,27.0,18.4,17.0,14.1$; MS (EI) $\mathrm{m} / \mathrm{z}$ (rel intensity) 435 (100); HRMS (EI) $\mathrm{m} / \mathrm{z}$ (molecular ion peak could not be detected) 435.0645 [435.0643 calcd for $\mathrm{C}_{20} \mathrm{H}_{24} \mathrm{OSiI},\left(\mathrm{M}-\mathrm{C}_{3} \mathrm{H}_{7}\right)$ ].

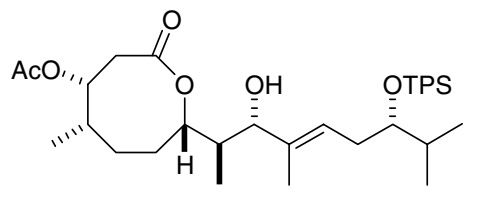

$53 b$

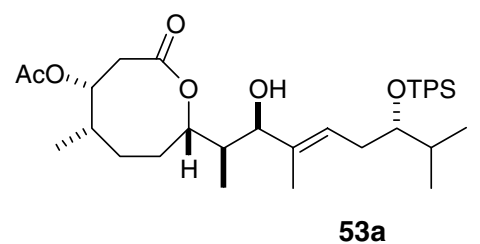

4(S),5(S),8(S)-4-Acetoxy-8-[(E),1(R),2(R),6(S)-6-(tert-butyldiphenylsilyloxy)-2-hydroxy-1,3,7trimethyl-oct-3-enyl]-5-methyl-oxocan-2-one 53a and $4(S), 5(S), 8(S)-4$-acetoxy-8$[(E), 1(R), 2(S), 6(S)-6$-(tert-butyldiphenylsilyloxy)-2-hydroxy-1,3,7-trimethyl-oct-3-enyl]-5-methyloxocan-2-one 53b. . The aldehyde $41(6.0 \mathrm{mg}, 23.2 \mu \mathrm{mol})$ was azeotropically evaporated twice with toluene $(2 \times 2 \mathrm{~mL})$ and freeze dried under high vacuum in a Schlenk flask prior to use. DMSO $(1 \mathrm{~mL})$ was added via syringe followed by the vinyl iodine $\mathbf{5 0}(90.3 \mathrm{mg}, 0.183 \mu \mathrm{mol})$ as a solution in DMSO via cannula $\left(0.5 \mathrm{~mL}, 0.5 \mathrm{~mL}\right.$ rinse). A mixture of $1 \% \mathrm{NiCl}_{2}$ in $\mathrm{CrCl}_{2}(30 \mathrm{mg}, 244 \mu \mathrm{mol})$ was preweighed in a glove box and added to the reaction mixture under a stream of Ar. The resultant dark green solution was stirred at ambient temperature with the exclusion of light for $22 \mathrm{~h}$ after which time it was quenched with saturated aqueous $\mathrm{NH}_{4} \mathrm{Cl}(8 \mathrm{~mL})$ and extracted with EtOAc $(5 \times 10 \mathrm{~mL})$. The combined organic extracts were washed with brine $(10 \mathrm{~mL})$ and dried $\left(\mathrm{Na}_{2} \mathrm{SO}_{4}\right)$. Concentration in vacuo was followed by flash chromatography (ethyl acetate:hexane, 1:4) to provide 53a (6.5 mg, 10.4 $\mu \mathrm{mol}, 44 \%)$ and $\mathbf{5 3 b}(3.5 \mathrm{mg}, 5.6 \mu \mathrm{mol}, 25 \%)$ as clear colorless oils. Data for 53a: $R_{f}$ (hexane:ethyl acetate, 3:1) 0.24; $[\alpha]_{\mathrm{D}}^{24}-23\left(c, 0.5, \mathrm{CHCl}_{3}\right) ;{ }^{1} \mathrm{H} \mathrm{NMR}\left(400 \mathrm{MHz}, \mathrm{CDCl}_{3}\right)$ 7.71-7.66 (m, 4H), 7.45-7.35 
$(\mathrm{m}, 6 \mathrm{H}), 5.07(\mathrm{t}, J=6.6 \mathrm{~Hz}, 1 \mathrm{H}), 5.02(\mathrm{t}, J=5.8 \mathrm{~Hz}, 1 \mathrm{H}), 4.71(\mathrm{dt}, J=12.9,4.3 \mathrm{~Hz}, 1 \mathrm{H}), 3.63(\mathrm{~m}$,

1H), $3.47(\mathrm{~d}, J=9.4 \mathrm{~Hz}, 1 \mathrm{H}), 2.95(\mathrm{dd}, J=13.9,5.8 \mathrm{~Hz}), 2.79(\mathrm{~d}, J=13.9 \mathrm{~Hz}, 1 \mathrm{H}), 2.17-2.01(\mathrm{~m}, 6 \mathrm{H}$,

$\left.\mathrm{CH}_{3} \mathrm{O}\right), 1.86-1.69(\mathrm{~m}, 5 \mathrm{H}), 1.39(\mathrm{~s}, 3 \mathrm{H}), 1.05(\mathrm{~s}, 9 \mathrm{H}), 0.95(\mathrm{~d}, J=6.8 \mathrm{~Hz}, 3 \mathrm{H}), 0.88(\mathrm{~d}, J=6.8 \mathrm{~Hz}, 6 \mathrm{H})$,

$0.66(\mathrm{~d}, J=6.8 \mathrm{~Hz}, 3 \mathrm{H}) ; \mathrm{MS}\left(\mathrm{CI}, \mathrm{NH}_{3}\right) \mathrm{m} / z$ (rel intensity) $640\left[30,\left(\mathrm{M}+\mathrm{NH}_{4}\right)^{+}\right] 151(100) ; \mathrm{HRMS}(\mathrm{CI}$,

$\left.\mathrm{NH}_{3}\right) m / z \quad 640.4030\left(640.4033\right.$ calcd for $\left.\mathrm{C}_{37} \mathrm{H}_{58} \mathrm{O}_{6} \mathrm{NSi}, \mathrm{MNH}_{4}\right)$. Data for 53b: $R_{f}$ (hexane:ethyl acetate,

3:1) 0.36; $[\alpha]_{\mathrm{D}}^{24}-54\left(c, 0.15, \mathrm{CHCl}_{3}\right) ;{ }^{1} \mathrm{H} \mathrm{NMR}\left(400 \mathrm{MHz}, \mathrm{CDCl}_{3}\right)$ 7.72-7.65 (m, 4H), 7.44-7.33 (m,

$6 \mathrm{H}), 5.15(\mathrm{t}, J=6.8 \mathrm{~Hz}, 1 \mathrm{H}), 5.04(\mathrm{~d}, J=5.9 \mathrm{~Hz}, 1 \mathrm{H}), 4.39-4.32(\mathrm{~m}, 1 \mathrm{H}), 3.99(\mathrm{~s}, 1 \mathrm{H}), 3.63(\mathrm{dd}, J=$ 9.5, $6.2 \mathrm{~Hz}, 1 \mathrm{H}), 2.94(\mathrm{dd}, J=13.6,5.9 \mathrm{~Hz}, 1 \mathrm{H}), 2.82(\mathrm{dd}, J=13.5,1.9 \mathrm{~Hz}, 1 \mathrm{H}), 2.20-2.04(\mathrm{~m}, 6 \mathrm{H})$, 1.80-1.60 (m, 5H), $1.31(\mathrm{~s}, 3 \mathrm{H}), 1.05(\mathrm{~s}, 9 \mathrm{H}), 0.94(\mathrm{~d}, J=6.9 \mathrm{~Hz}, 3 \mathrm{H}), 0.62(\mathrm{~d}, J=7.0 \mathrm{~Hz}, 3 \mathrm{H})$.

\section{Proof of Stereochemistry at C2' of 53a}

The corresponding $(R)$ and $(S)$ Mosher esters of 53a were prepared. Relevant ${ }^{1} \mathrm{H}$ NMR data is shown in Figure 3.

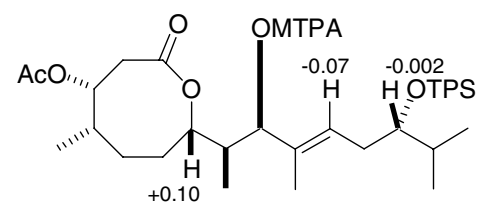

Figure 3. $\Delta \delta\left(\delta_{S}-\delta_{R}\right)$ values (in ppm) for the $(R)$ and $(S)$ Mosher esters prepared from 53a. According to the Kakisawa model $^{8}$ the absolute stereochemistry of C2' in 53a is therefore $(R)$.

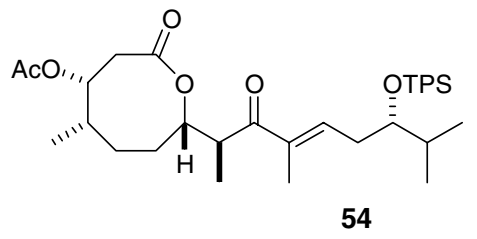

4(R),5(S),8(S)-4-Acetoxy-8-[(E),1(S),6(R)-6-(tert-butyldiphenylsiloxy)-1,3,7-trimethyl-2-oxo-oct3-enyl]-5-methyl-oxocan-2-one 54. To a solution of $53(7 \mathrm{mg}, 11.2 \mu \mathrm{mol})$ in $\mathrm{CH}_{2} \mathrm{Cl}_{2}(2 \mathrm{~mL})$ was added the Dess Martin periodinane $(34 \mathrm{mg}, 80 \mu \mathrm{mol})$. The mixture was stirred at ambient temperature 
for $2 \mathrm{~h}$. The solvent was exchanged with EtOAc and the reagent was removed by passing the mixture through a short plug of Florisil ${ }^{\mathrm{TM}}$, eluting with EtOAc. The crude product was purified by flash chromatography (hexane:ethyl acetate, 6:1 to 5:1) to furnish the title compound 54 (5.0 $\mathrm{mg}, 8.05$ $\mu \mathrm{mol}, 72 \%)$ as a colorless oil; $R_{f}$ (hexane:ethyl acetate, $\left.1: 1\right) 0.63 ;[\alpha]_{\mathrm{D}}^{22}-25\left(\mathrm{c} 0.4, \mathrm{CDCl}_{3}\right) ;{ }^{1} \mathrm{H}$ NMR $\left(400 \mathrm{MHz}, \mathrm{CDCl}_{3}\right) \delta$ •7.71-7.66 (m, $\left.5 \mathrm{H}\right), 7.46-7.34(\mathrm{~m}, 5 \mathrm{H}), 6.55(\mathrm{t}, J 6.6 \mathrm{~Hz}, 1 \mathrm{H}), 5.04(\mathrm{~s}, 1 \mathrm{H}), 4.78-$ $4.63(\mathrm{td}, J 11,3 \mathrm{~Hz}, 1 \mathrm{H}), 3.71(\mathrm{~m}, 1 \mathrm{H}), 3.25-3.05(\mathrm{~m}, 1 \mathrm{H}), 3.02-2.84(\mathrm{~m}, 2 \mathrm{H}), 2.37-2.28(\mathrm{~m}, 2 \mathrm{H}), 2.08$ $(\mathrm{s}, 3 \mathrm{H}), 1.55(\mathrm{~s}, 1 \mathrm{H}), 1.06(\mathrm{~s}, 9 \mathrm{H}) ;{ }^{13} \mathrm{C} \mathrm{NMR}\left(100 \mathrm{MHz}, \mathrm{CDCl}_{3}\right) \delta \cdot 202.7,170.7,170.6,141.3,136.8$, 136.0, 135.9, 134.4, 133.4, 133.4, 129.8, 129.6, 127.7, 127.5, 76.5, 73.1, 44.1, 36.4, 35.5, 33.5, 33.1, 29.0, 27.0, 26.7, 24.0, 22.6, 21.7, 20.1, 19.5, 17.7, 17.6, 15.2, 14.1, 11.6, 11.4; IR (CDCl $)_{3} 1740,1663$, 1240, $913 \mathrm{~cm}^{-1}$; MS (CI, NH $)$ m/z (rel intensity) 641 (10), 311 (11), 169 (15), 77 (100); HRMS (CI, $\left.\mathrm{NH}_{3}\right) \mathrm{m} / \mathrm{z} 638.3880\left(638.3877\right.$ calcd for $\left.\mathrm{C}_{37} \mathrm{H}_{56} \mathrm{O}_{6} \mathrm{NSi}, \mathrm{MNH}_{4}\right)$.

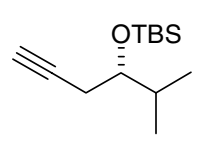

(S)-4-(tert-Butyldimethylsiloxy)-5-methyl-1-hexyne. A solution of 51 (4.0 g, $35 \mathrm{mmol})$, tertbutyldimethylsilylchloride $(15.7 \mathrm{~g}, 105 \mathrm{mmol})$ and imidazole $(14.3 \mathrm{~g}, 210 \mathrm{mmol})$ in 1:1 toluene:DMF $(120 \mathrm{~mL})$ was stirred at ambient temperature for $72 \mathrm{~h}$. The mixture was diluted with water $(250 \mathrm{~mL})$ and was extracted with EtOAc:hexane, 1:1 $(3 \times 100 \mathrm{~mL})$. The combined organic extracts were washed with brine and dried $\left(\mathrm{MgSO}_{4}\right)$. Evaporation in vacuo provided the crude product, purified by flash chromatography (hexane) to give the title compound (3.3 g, $0.0146 \mathrm{mmol}, 35 \%$ over 2 steps) as a clear colorless liquid; $R_{f}\left(10 \%\right.$ EtOAc/hexane) $0.71 ;[\alpha]_{\mathrm{D}}+9.3\left(c 2.1, \mathrm{CDCl}_{3}\right) ;{ }^{1} \mathrm{H} \mathrm{NMR}\left(400 \mathrm{MHz}, \mathrm{CDCl}_{3}\right)$ $\delta 3.60(\mathrm{~m}, 1 \mathrm{H}), 2.30(\mathrm{~d}, J=5.0 \mathrm{~Hz}, 2 \mathrm{H}), 1.93(\mathrm{~d}, J=2.3 \mathrm{~Hz}, 1 \mathrm{H}), 1.97-1.85(\mathrm{~m}, 1 \mathrm{H}), 0.96-0.85(\mathrm{~m}$, 15H), 0.09-0.04 (m, 6H); ${ }^{13} \mathrm{CNMR}\left(100 \mathrm{MHz} \mathrm{CDCl}_{3}\right) \delta$ 82.1, 75.2, 69.6, 32.3, 25.8, 24.6, 19.0, 18.1, 16.3, -4.3, -4.7; IR $\left(\mathrm{CDCl}_{3}\right) 3308,2118 \mathrm{~cm}^{-1}$. 


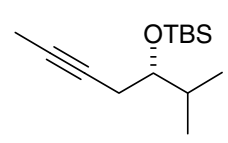

(S)-5-(tert-Butyldimethylsiloxy)-6-methyl-2-heptyne. $\quad$ To a solution of $(S)$-4-(tertbutyldimethylsiloxy)-5-methyl-1-hexyne $(291 \mathrm{mg}, 1.25 \mathrm{mmol})$ in dry THF $(8 \mathrm{~mL})$ at $-78{ }^{\circ} \mathrm{C}$ was added $n$-BuLi (1.1 mL, 1.6 M in hexane, $1.76 \mathrm{mmol})$ dropwise via syringe and the mixture was stirred for 20 min. Methyl iodide $(135 \mu \mathrm{L}, 2.17 \mathrm{mmol})$ was added via syringe and the mixture was allowed to warm to $0{ }^{\circ} \mathrm{C}$ over $1.5 \mathrm{~h}$. It was then warmed to ambient temperature and stirred for $30 \mathrm{~min}$ after which the reaction was quenched with water $(20 \mathrm{~mL})$. The mixture was extracted with $\mathrm{Et}_{2} \mathrm{O}(3 \times 20 \mathrm{~mL})$. The combined organic layers were dried $\left(\mathrm{MgSO}_{4}\right)$, filtered, and evaporated in vacuo at $-5{ }^{\circ} \mathrm{C}$. The residue was passed through a short plug of silica (hexane) to give the title compound as a clear colorless oil (263 mg, $1.09 \mathrm{~mol}, 88 \%) ; R_{f}$ (hexane) $0.58 ;[\alpha]_{\mathrm{D}}^{20}+5.7\left(c 5.0, \mathrm{CDCl}_{3}\right) ;{ }^{1} \mathrm{H}\left(400 \mathrm{MHz}, \mathrm{CDCl}_{3}\right) \delta 3.58(\mathrm{dt}$, $J=6.4,3.7 \mathrm{~Hz}, 1 \mathrm{H}), 2.23-2.21(\mathrm{~m}, 2 \mathrm{H}), 1.92-1.80(\mathrm{~m}, 1 \mathrm{H}), 1.75(\mathrm{t}, J=2.5 \mathrm{~Hz}, 3 \mathrm{H}), 0.78-0.97(\mathrm{~m}$, 15H), 0.06 (s, 3H), $0.03(\mathrm{~s}, 3 \mathrm{H}) ;{ }^{13} \mathrm{C}\left(100 \mathrm{MHz}, \mathrm{CDCl}_{3}\right) \delta$ 76.7, 75.7, 75.2, 32.2, 25.9, 24.8, 19.1, 16.1, $18.1,, 3.5,,-4.3,-4.8 ; \mathrm{IR}\left(\mathrm{CDCl}_{3}\right) 1918,1253 \mathrm{~cm}^{-1}$.

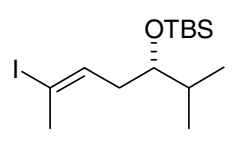

$56 a$

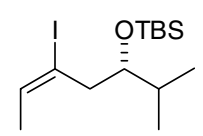

$56 b$

\section{$(E),(S)-5$-(tert-Butyldimethylsiloxy)-6-methyl-2-iodo-2-heptene, $\quad 56 a \quad$ and $\quad(E),(S)-5$-(tert-} butyldimethylsiloxy)-6-methyl-3-iodo-2-heptene 56b. Cyclopentadienyl zirconium hydride chloride (330 mg, $1.28 \mathrm{mmol}$ ) was pre-weighed in a glove box and transferred to an oven dried Schlenck tube under a stream of Ar. The flask was then flushed with argon and degassed benzene $(2.0 \mathrm{~mL})$ was added via syringe. (S)-5-(tert-Butyldimethylsiloxy)-6-methyl-2-heptyne (95 $\mathrm{mg}, 0.395 \mathrm{mmol}$ ) was then added via cannula as a solution in benzene $(1.0 \mathrm{~mL}+0.5 \mathrm{~mL}$ wash). The mixture was stirred under Ar with the exclusion of light at $40{ }^{\circ} \mathrm{C}$ for a period of $4 \mathrm{~h}$. It was then allowed to cool to ambient temperature $(15 \mathrm{~min})$ and was cooled to $5{ }^{\circ} \mathrm{C} . \mathrm{I}_{2}(210 \mathrm{mg}, 0.83 \mathrm{mmol})$ was added via syringe 
as a solution in THF $(0.4 \mathrm{M})$, titrating it until the color change persisted. The mixture was allowed to warm to ambient temperature and stirred for $30 \mathrm{~min} .5 \% \mathrm{w} / \mathrm{v} \mathrm{Na} \mathrm{S}_{2} \mathrm{O}_{3}(2.5 \mathrm{~mL})$ was added to quench the reaction (a white precipitate resulted) and the flask was stirred vigorously for $10 \mathrm{~min}$. The mixture was filtered through a short plug of Celite ${ }^{\mathrm{TM}}$ eluting with EtOAc $(30 \mathrm{~mL})$. Water $(20 \mathrm{~mL})$ was added to the eluent and the aqueous layer was washed with EtOAc $(3 \times 20 \mathrm{~mL})$. The combined organic extracts were dried $\left(\mathrm{MgSO}_{4}\right)$ and evaporated. Purification by flash chromatography (hexane) gave the regioisomeric products $\mathbf{5 6 a}(105 \mathrm{mg}, 0.285 \mathrm{mmol}, 70 \%)$ and $\mathbf{5 6 b}(10 \mathrm{mg}, 0.027 \mathrm{mmol}, 7 \%)$. Data for 56a: $R_{f}$ (hexane) $0.5 ;[\alpha]_{\mathrm{D}}^{20}-6.5\left(c 0.65, \mathrm{CH}_{2} \mathrm{Cl}_{2}\right) ;{ }^{1} \mathrm{H} \mathrm{NMR}\left(400 \mathrm{MHz}, \mathrm{CDCl}_{3}\right) \delta 6.17(\mathrm{~m}, 1 \mathrm{H}), 3.48(\mathrm{dt}$, $J=6.6,5.0 \mathrm{~Hz}, 1 \mathrm{H}), 2.37(\mathrm{~s}, 3 \mathrm{H}), 2.20-2.06(\mathrm{~m}, 2 \mathrm{H}), 1.74-1.66(\mathrm{~m}, 1 \mathrm{H}), 0.89(\mathrm{~s}, 9 \mathrm{H}), 0.87(\mathrm{~d}, J=6.8$ $\mathrm{Hz}, 3 \mathrm{H}), 0.85(\mathrm{~d}, J=6.8 \mathrm{~Hz}, 3 \mathrm{H}), 0.05(\mathrm{~s}, 3 \mathrm{H}), 0.03(\mathrm{~s}, 3 \mathrm{H}) ;{ }^{13} \mathrm{C} \mathrm{NMR}\left(100 \mathrm{MHz}, \mathrm{CDCl}_{3}\right) \delta 138.6$, 94.5, 75.9, 34.8, 33.1, 27.7, 25.9, 18.2, 17.5, -4.6, -4.2; IR (film) 2958, 2929, 1472, $\mathrm{cm}^{-1}$; MS (EI) m/z (rel intensity) 367 [10]; HRMS (EI) $\mathrm{m} / z \quad 368.1050$ (368.1034 calcd for $\mathrm{C}_{14} \mathrm{H}_{29}$ OSiI, MH).

Data for 56b. $R_{f}$ (hexane) $0.55 ;[\alpha]_{\mathrm{D}}^{20}-8.5\left(c 0.8, \mathrm{CH}_{2} \mathrm{Cl}_{2}\right) ;{ }^{1} \mathrm{H} \mathrm{NMR}\left(400 \mathrm{MHz}, \mathrm{CDCl}_{3}\right) \delta 6.28(\mathrm{q}, J$ $=7.1 \mathrm{~Hz}, 1 \mathrm{H}), 3.82(\mathrm{ddd}, J=7.6,4.8,3.0 \mathrm{~Hz}, 1 \mathrm{H}), 2.56(\mathrm{dd}, J=14.3,7.4 \mathrm{~Hz}, 1 \mathrm{H}), 2.34(\mathrm{dd}, J=14.4$, $4.9 \mathrm{~Hz}, 1 \mathrm{H}), 1.74(\mathrm{~m}, 1 \mathrm{H}), 1.66(\mathrm{~d}, J=7.1 \mathrm{~Hz}, 3 \mathrm{H}), 0.92(\mathrm{~d}, J=6.9 \mathrm{~Hz}, 3 \mathrm{H}), 0.89(\mathrm{~s}, 9 \mathrm{H}), 0.86(\mathrm{~d}, J=$ $6.9 \mathrm{~Hz}, 3 \mathrm{H}), 0.08(\mathrm{~s}, 3 \mathrm{H}), 0.07$ (s, 3H); ${ }^{13} \mathrm{C} \mathrm{NMR}\left(100 \mathrm{MHz}, \mathrm{CDCl}_{3}\right) \delta$ 137.4, 101.0, 75.4, 41.6, 32.6, $25.9,18.1,18.0,16.9,-3.9,-4.7$.

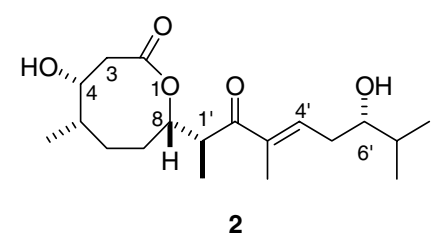

Table 1. Comparison of the ${ }^{13} \mathrm{C}$ NMR data of synthetic and natural ${ }^{11}$ octalactin $\mathrm{B}(\mathbf{2})$.

\begin{tabular}{|l|c|c|c|}
\hline \multicolumn{1}{|c|}{ Carbon } & $\delta_{\mathrm{C}}$ Synthetic $^{a}$ & $\delta_{\mathrm{C}}$ Natural $^{b}$ & $\left|\delta_{\text {Nat }}-\delta_{\text {Syn }}\right|$ \\
\hline C2 & 203.3 & 203.3 & 0 \\
\hline C2 & 172.5 & 172.6 & 0.1 \\
\hline
\end{tabular}




\begin{tabular}{|c|c|c|c|}
\hline C4' & 141.4 & 141.4 & 0 \\
\hline C3' & 137.5 & 137.5 & 0 \\
\hline C8 & 79.4 & 79.4 & 0 \\
\hline C6' & 75.9 & 75.8 & 0.1 \\
\hline C4 & 71.4 & 71.4 & 0 \\
\hline $\mathrm{C} 1{ }^{\prime}$ & 44.2 & 44.3 & 0.1 \\
\hline C3 & 39.2 & 39.2 & 0 \\
\hline C7' & 38.0 & 38.0 & 0.1 \\
\hline C5 & 34.1 & 34.1 & 0 \\
\hline C5 & 33.9 & 33.9 & 0 \\
\hline C7 & 32.2 & 32.2 & 0 \\
\hline C6 & 22.6 & 22.7 & 0.1 \\
\hline $\mathrm{CH}_{3}-7^{\prime}$ & 22.0 & 22.0 & 0 \\
\hline $\mathrm{CH}_{3}-5$ & 18.7 & 18.7 & 0 \\
\hline $\mathrm{CH}_{3}-\mathrm{T}^{\prime}$ & 17.4 & 17.4 & 0 \\
\hline $\mathrm{CH}_{3}-3^{\prime}$ & 15.0 & 14.9 & 1 \\
\hline $\mathrm{CH}_{3}-1$ ' & 11.7 & 11.7 & 0 \\
\hline
\end{tabular}

${ }^{a}$ Spectrum run at $100 \mathrm{MHz}$ in $\mathrm{CDCl}_{3} \cdot{ }^{b}$ Spectrum run at $50 \mathrm{MHz}$ in $\mathrm{CDCl}_{3}$.

Table 2. Comparison of the ${ }^{1} \mathrm{H}$ NMR data of synthetic and natural ${ }^{11}$ octalactin B (2).

\begin{tabular}{|l|l|l|c|}
\hline \multicolumn{1}{|c|}{ Proton } & \multicolumn{1}{|c|}{$\delta_{\mathrm{H}}$ Synthetic $^{a}$} & \multicolumn{1}{|c|}{$\delta_{\mathrm{H}}$ Natural $^{b, c}$} & $\left|\delta_{\mathrm{Nat}} \delta_{\mathrm{Syn}}\right|$ \\
\hline H4' & $6.86, \mathrm{t}, J=7.0 \mathrm{~Hz}$ & $6.87, \mathrm{t}, J=6.8 \mathrm{~Hz}$ & 0.01 \\
\hline $\mathrm{H} 8$ & $4.75, \mathrm{t}, J=10.7 \mathrm{~Hz}$ & $4.76, \mathrm{br} \mathrm{t}, J=9.7 \mathrm{~Hz}$ & 0.01 \\
\hline $\mathrm{H} 4$ & $4.03, \mathrm{br} \mathrm{s}$ & $4.04, \mathrm{br} \mathrm{s}$ & 0.01 \\
\hline $\mathrm{H}^{\prime}, \mathrm{H}^{\prime}$ & $3.56-3.51, \mathrm{~m}$ & $3.55, \mathrm{qu}, J=7.2 \mathrm{~Hz}, 3.52, \mathrm{br} \mathrm{s}$ & - \\
\hline
\end{tabular}




\begin{tabular}{|c|c|c|c|}
\hline $\mathrm{H} 3_{\mathrm{a}}$ & $\begin{array}{l}3.05, \mathrm{dd}, J=13.3,1.5 \\
\mathrm{~Hz}\end{array}$ & $3.05, \mathrm{dd}, J=13.3,1.8$ & 0 \\
\hline $\mathrm{H} 3_{\mathrm{b}}$ & $2.72, \mathrm{dd}, J=13.3,6.5$ & $2.70, \mathrm{dd}, J=13.3,6.1$ & 0.02 \\
\hline $\mathrm{H} 5{ }_{\mathrm{a}}$ & $2.45, \mathrm{~m}$ & $2.45 \mathrm{ddd}, J=15.1,6.8,3.6$ & 0 \\
\hline $\mathrm{H} 5{ }^{\prime}$ & $2.35, \mathrm{~m}$ & Not listed & - \\
\hline $\mathrm{OH}$ & $1.96, \mathrm{~d}, J=4.8 \mathrm{~Hz}$ & Not listed & - \\
\hline $\mathrm{H} 7_{\mathrm{a}}, \mathrm{H} 7_{b}, \mathrm{H} 6_{\mathrm{a}}, \mathrm{H} 5, \mathrm{H} 7$ & $1.81-1.74,1.73-1.68, \mathrm{~m}$ & $1.80,1.70,1.65,1.60, \mathrm{~m}$ & - \\
\hline $\mathrm{CH}_{3}-1^{\prime}$ & $1.78, \mathrm{~s}$ & $1.78, \mathrm{~s}$ & 0 \\
\hline $\mathrm{H}_{\mathrm{b}}$ & $1.24-1.18, \mathrm{~m}$ & $1.23, \mathrm{~m}$ & 0 \\
\hline $\mathrm{CH}_{3}-7$ & $1.14, \mathrm{~d}, J=7.1 \mathrm{~Hz}$ & $1.14, \mathrm{~d}, J=7.2 \mathrm{~Hz}$ & 0 \\
\hline $\mathrm{CH}_{3}-1^{\prime}$ & $1.05, \mathrm{~d}, J=7.2 \mathrm{~Hz}$ & $1.05, \mathrm{~d}, J=7.2 \mathrm{~Hz}$ & 0 \\
\hline $\mathrm{CH}_{3}-5$ & $0.98, \mathrm{~d}, J=6.6 \mathrm{~Hz}$ & $0.97, \mathrm{~d}, J=6.8 \mathrm{~Hz}$ & 0.01 \\
\hline $\mathrm{CH}_{3}-7$ & $0.96, \mathrm{~d}, J=6.8 \mathrm{~Hz}$ & $0.96, \mathrm{~d}, J=6.8 \mathrm{~Hz}$ & 0 \\
\hline
\end{tabular}

${ }^{a}$ Spectrum run at $500 \mathrm{MHz}$ in $\mathrm{CDCl}_{3} .{ }^{b}$ Spectrum run at $360 \mathrm{MHz}$ in $\mathrm{CDCl}_{3}$. ${ }^{c}$ Protons which form part of an unresolved multiplet were not listed in the original isolation paper. ${ }^{11}$

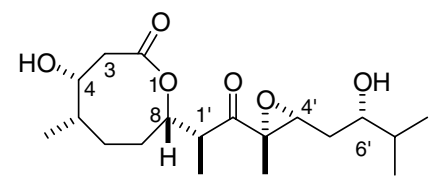

1

Table 3. Comparison of the ${ }^{13} \mathrm{C}$ NMR data of synthetic and natural ${ }^{11}$ octalactin $\mathrm{A}(\mathbf{1})$.

\begin{tabular}{|l|c|c|c|}
\hline \multicolumn{1}{|c|}{ Carbon } & $\delta_{\mathrm{C}}$ Synthetic $^{a}$ & $\delta_{\mathrm{C}}$ Natural $^{b}$ & $\left|\delta_{\text {Nat }}-\delta_{\text {syn }}\right|$ \\
\hline C2' & 212.5 & 212.4 & 0.1 \\
\hline C2 & 172.5 & 172.4 & 0.1 \\
\hline C8 & 79.3 & 79.3 & 0 \\
\hline C6 & 74.5 & 74.5 & 0 \\
\hline
\end{tabular}




\begin{tabular}{|c|c|c|c|}
\hline $\mathrm{C} 4$ & 71.3 & 71.3 & 0 \\
\hline C3' & 62.4 & 62.4 & 0.0 \\
\hline C4' & 58.9 & 58.8 & 0.1 \\
\hline $\mathrm{C} 1^{\prime}$ & 42.4 & 42.5 & 0.1 \\
\hline C3 & 39.2 & 39.3 & 0.1 \\
\hline C7' & 38.0 & 38.0 & 0.1 \\
\hline $\mathrm{C} 5$ & 34.0 & 34.0 & 0 \\
\hline C5' & 32.2 & 32.3 & 0.1 \\
\hline C7 & 32.0 & 32.0 & 0 \\
\hline C6 & 22.4 & 22.5 & 0.1 \\
\hline $\mathrm{CH}_{3}-7^{\prime}$ & 22.1 & 22.0 & 0.1 \\
\hline $\mathrm{CH}_{3}-5$ & 18.5 & 18.4 & 0.1 \\
\hline $\mathrm{CH}_{3}-7^{\prime}$ & 17.6 & 17.6 & 0 \\
\hline $\mathrm{CH}_{3}-3^{\prime}$ & 13.5 & 13.4 & 0.1 \\
\hline $\mathrm{CH}_{3}-1$, & 12.6 & 12.6 & 0 \\
\hline
\end{tabular}

${ }^{a}$ Spectrum run at $100 \mathrm{MHz}$ in $\mathrm{CDCl}_{3} \cdot{ }^{b}$ Spectrum run at $50 \mathrm{MHz}$ in $\mathrm{CDCl}_{3}$.

Table 4. Comparison of the ${ }^{1} \mathrm{H}$ NMR data of synthetic and natural ${ }^{11}$ octalactin A (2).

\begin{tabular}{|l|l|l|c|}
\hline \multicolumn{1}{|c|}{ Proton } & \multicolumn{1}{|c|}{$\delta_{\mathrm{H}}$ Synthetic $^{a}$} & \multicolumn{1}{|c|}{$\delta_{\mathrm{H}}$ Natural $^{b, c}$} & $\left|\delta_{\text {Nat }} \delta_{\text {Syn }}\right|$ \\
\hline H8 & $4.60, \mathrm{t}, J=10.3 \mathrm{~Hz}$ & $4.60, \mathrm{t}, J=9.7 \mathrm{~Hz}$ & 0 \\
\hline $\mathrm{H} 4$ & $4.03, \mathrm{br} \mathrm{s}$ & $4.03, \mathrm{br} \mathrm{s}$ & 0 \\
\hline $\mathrm{H} 4^{\prime}$ & $3.55, \mathrm{t}, J=6.2 \mathrm{~Hz}$ & $3.55, \mathrm{t}, J=6.2 \mathrm{~Hz}$ & 0 \\
\hline $\mathrm{H} 6$ & & $3.50, \mathrm{~m}$ & - \\
\hline $\mathrm{H} 1^{\prime}$ & $3.58-3.48, \mathrm{~m}$ & $2.96, \mathrm{~m}$ & - \\
\hline $\mathrm{OH}$ & $3.00-2.93, \mathrm{~m}$ & Not listed & - \\
\hline
\end{tabular}




\begin{tabular}{|l|l|l|c|}
\hline $\mathrm{H}_{\mathrm{a}}$ & $\begin{array}{l}2.72, \mathrm{dd}, J=13.4,6.3 \\
\mathrm{~Hz}\end{array}$ & $2.72, \mathrm{dd}, J=13.3,6.1$ & 0 \\
\hline $\mathrm{OH}$ & $1.89, \mathrm{brd}, J=3.1 \mathrm{~Hz}$ & Not listed & - \\
\hline $\mathrm{H} 5, \mathrm{H}^{\mathrm{a}}, \mathrm{H}_{\mathrm{a}}, \mathrm{H}_{\mathrm{b}}, \mathrm{H}^{\prime}{ }_{\mathrm{a}}, \mathrm{H}^{\prime}{ }^{\prime}, \mathrm{H} 7$ & $1.79-1.57, \mathrm{~m}$ & Not listed & - \\
\hline $\mathrm{CH}_{3}-1{ }^{\prime}$ & $1.44, \mathrm{~s}$ & $1.44, \mathrm{~s}$ & 0 \\
\hline $\mathrm{H}_{\mathrm{b}}$ & $1.23-1.18, \mathrm{~m}$ & Not listed & - \\
\hline $\mathrm{CH}_{3}-7$ & $1.13, \mathrm{~d}, J=7.1 \mathrm{~Hz}$ & $1.14, \mathrm{~d}, J=6.8 \mathrm{~Hz}$ & 0 \\
\hline $\mathrm{CH}_{3}-3{ }^{\prime}$ & $1.00, \mathrm{~d}, J=7.0 \mathrm{~Hz}$ & $1.00, \mathrm{~d}, J=6.8 \mathrm{~Hz}$ & 0 \\
\hline $\mathrm{CH}_{3}-7{ }^{\prime}$ & $0.94, \mathrm{~d}, J=6.8 \mathrm{~Hz}$ & $0.94, \mathrm{~d}, J=6.8 \mathrm{~Hz}$ & 0 \\
\hline $\mathrm{CH}_{3}-5$ & $0.92, \mathrm{~d}, J=6.8 \mathrm{~Hz}$ & $0.92, \mathrm{~d}, J=6.8 \mathrm{~Hz}$ & 0 \\
\hline
\end{tabular}

${ }^{a}$ Spectrum run at $500 \mathrm{MHz}$ in $\mathrm{CDCl}_{3} .{ }^{b}$ Spectrum run at $360 \mathrm{MHz}$ in $\mathrm{CDCl}_{3}$. ${ }^{c}$ Protons which form part of an unresolved multiplet were not listed in the original isolation paper. ${ }^{11}$

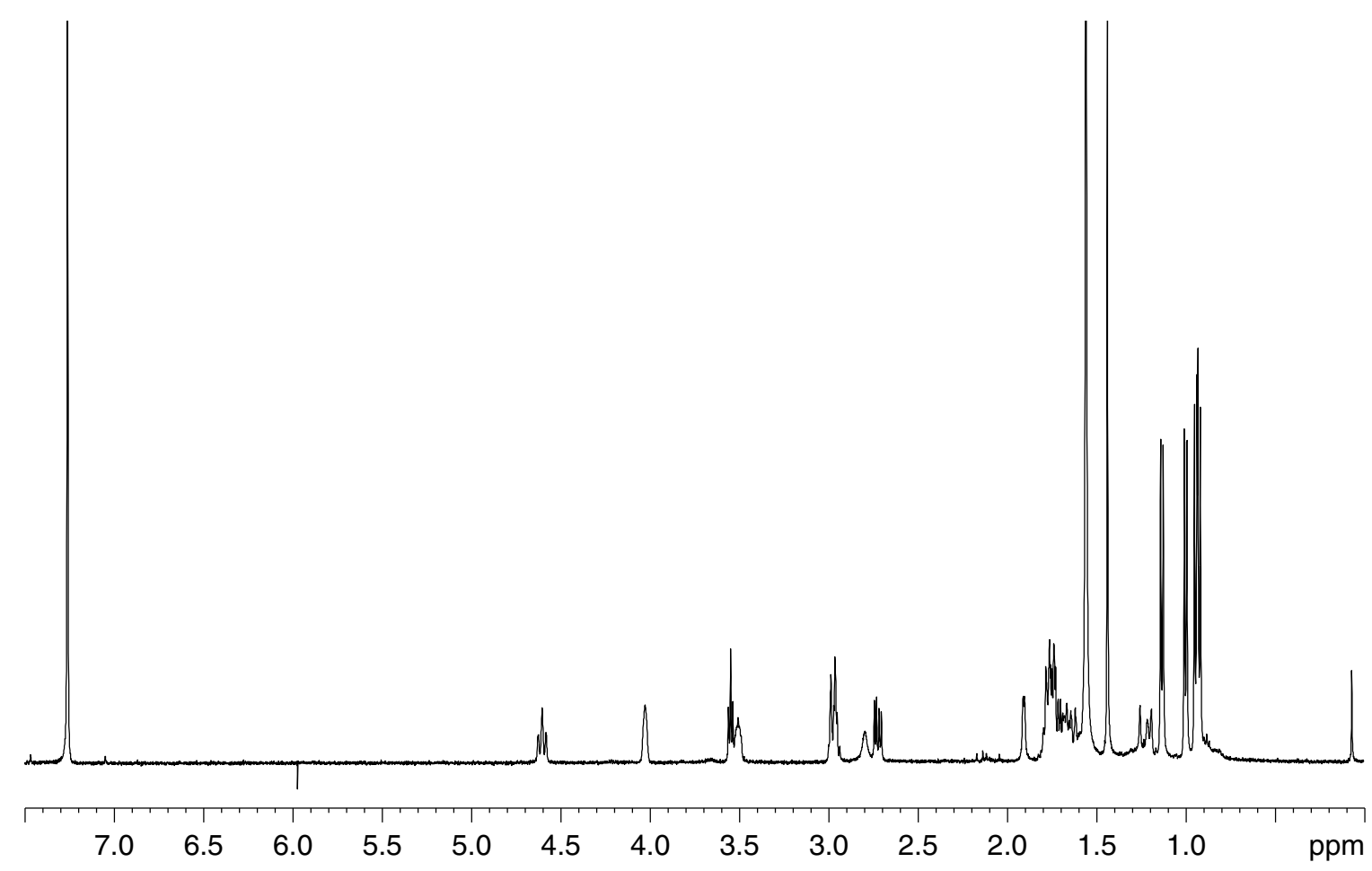




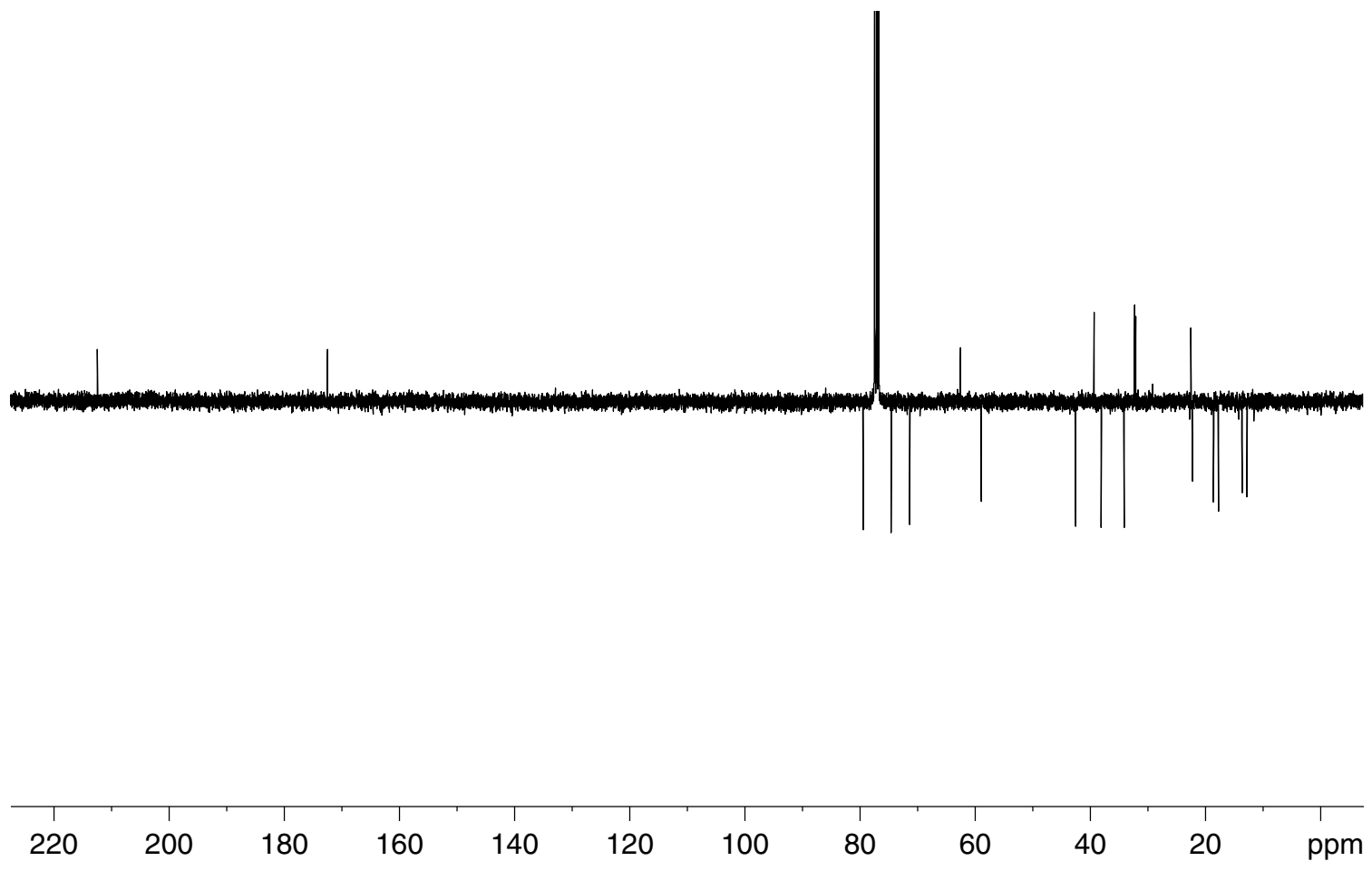

Figure 4. ${ }^{1} \mathrm{H} \mathrm{NMR}\left(500 \mathrm{MHz}, \mathrm{CDCl}_{3}\right)$ and $\left.{ }^{13} \mathrm{C} \mathrm{NMR} \mathrm{(100} \mathrm{MHz}, \mathrm{CDCl}_{3} \mathrm{APT}\right)$ of synthetic (-)octalactin A 1.

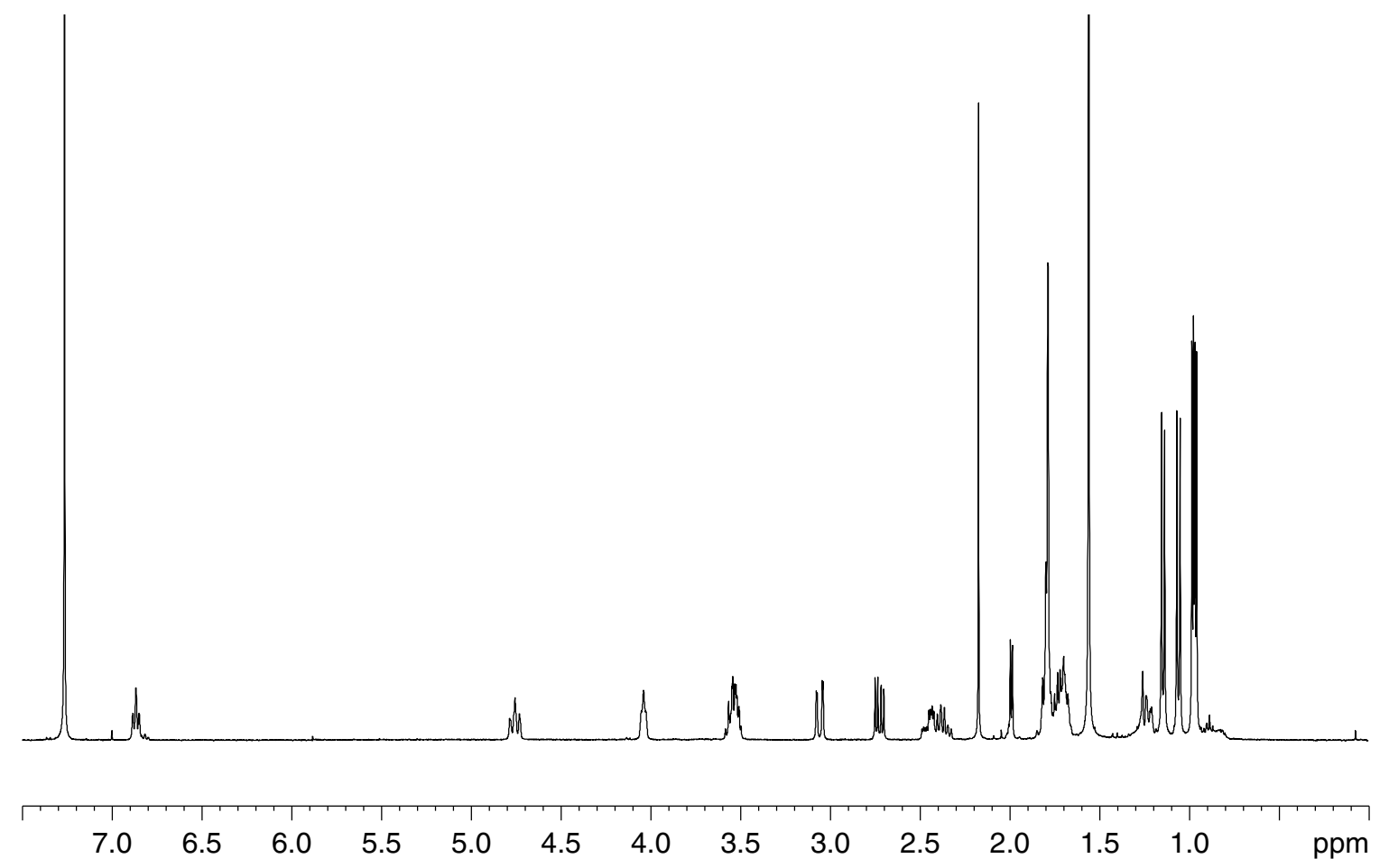




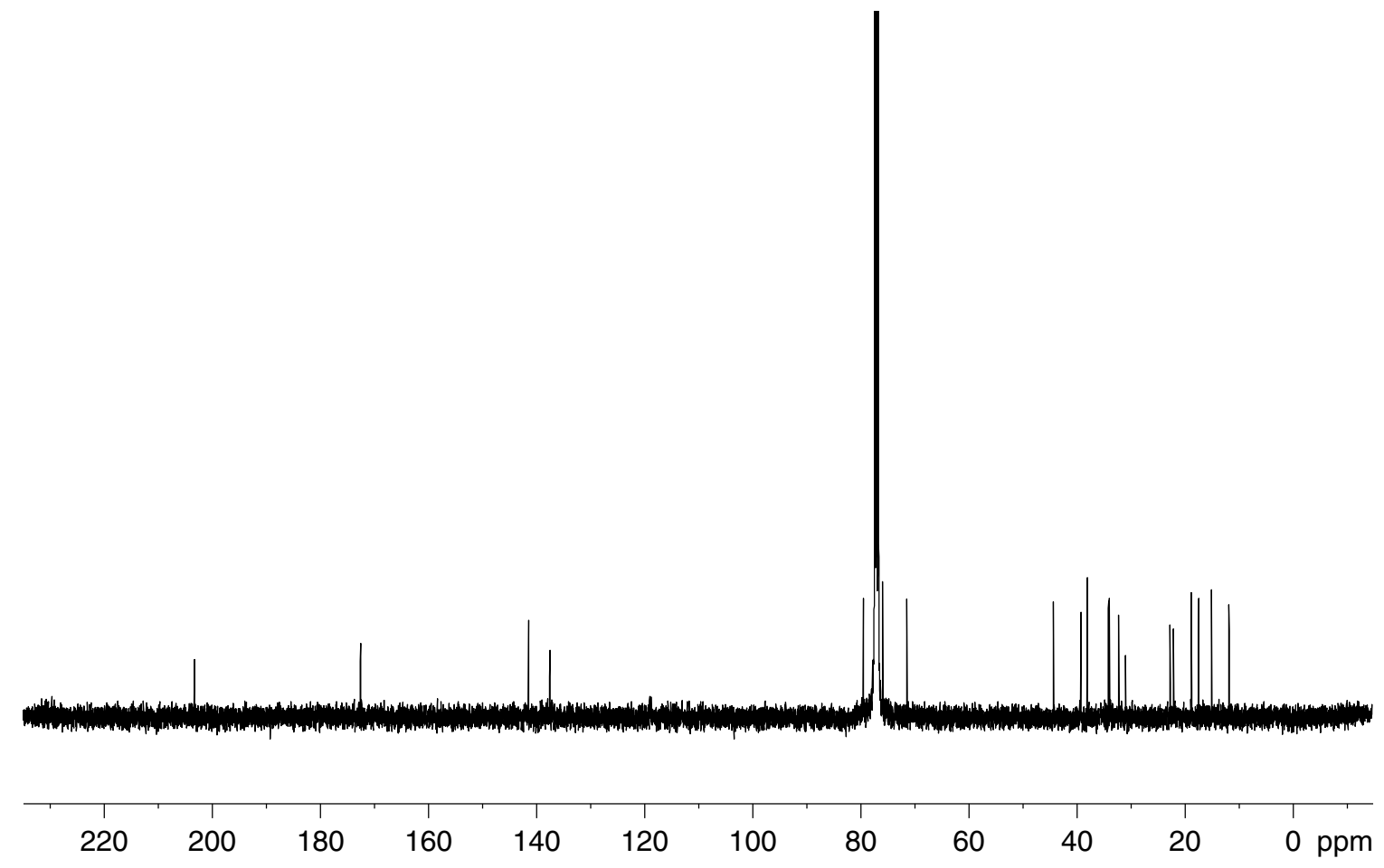

Figure 5. ${ }^{1} \mathrm{H} \mathrm{NMR}\left(400 \mathrm{MHz}, \mathrm{CDCl}_{3}\right)$ and ${ }^{13} \mathrm{C} \mathrm{NMR}\left(100 \mathrm{MHz}, \mathrm{CDCl}_{3}\right)$ of synthetic (-)-octalactin $\mathrm{B}$ 2.<smiles>CC(=O)O[C@@H]1C[C@@H](O)[C@@H](C)COC(=O)C/C=C\1C</smiles>

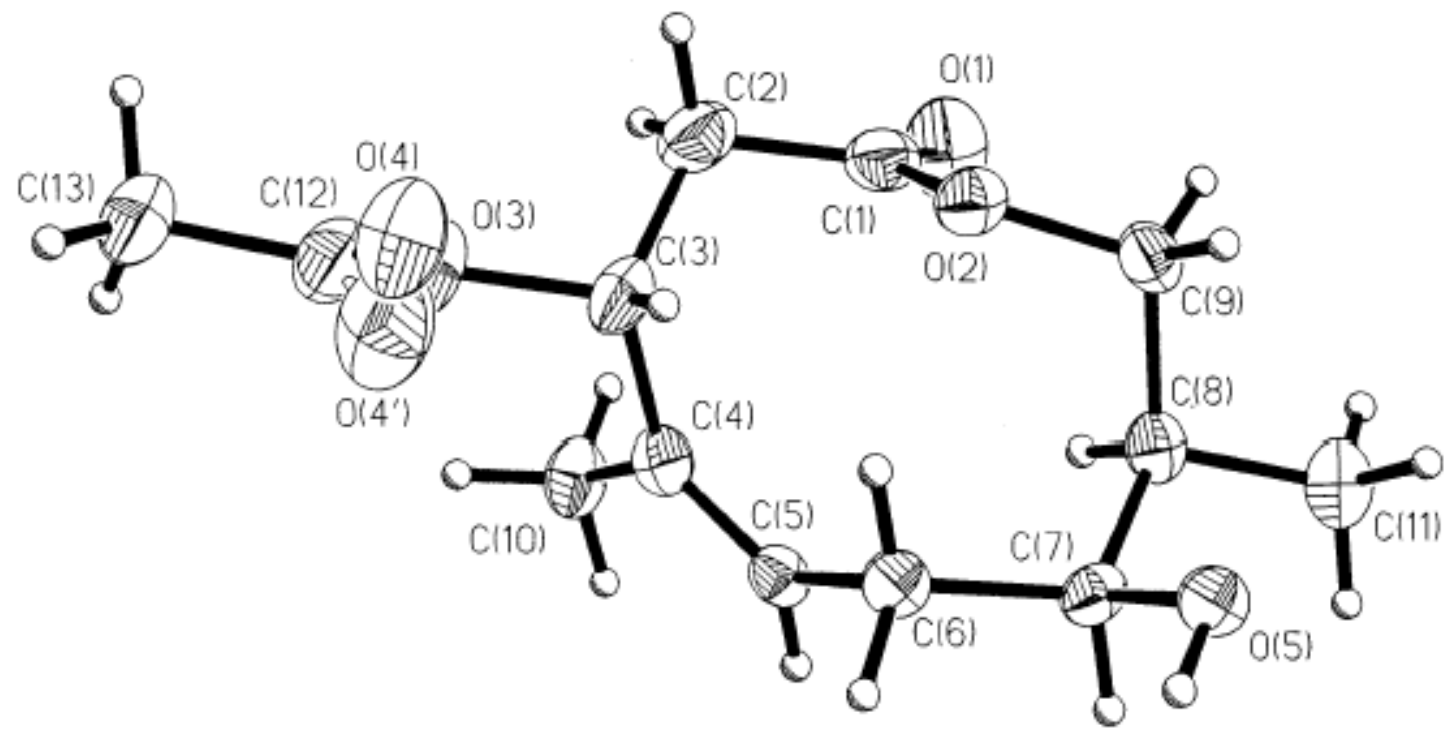


Figure 6. The X-ray crystal structure of the lactone 48. The acetate carbonyl oxygen atom is disordered.

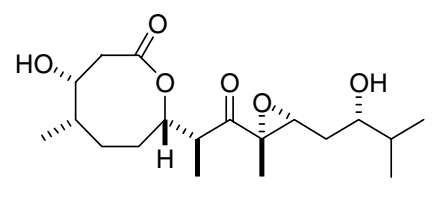

1

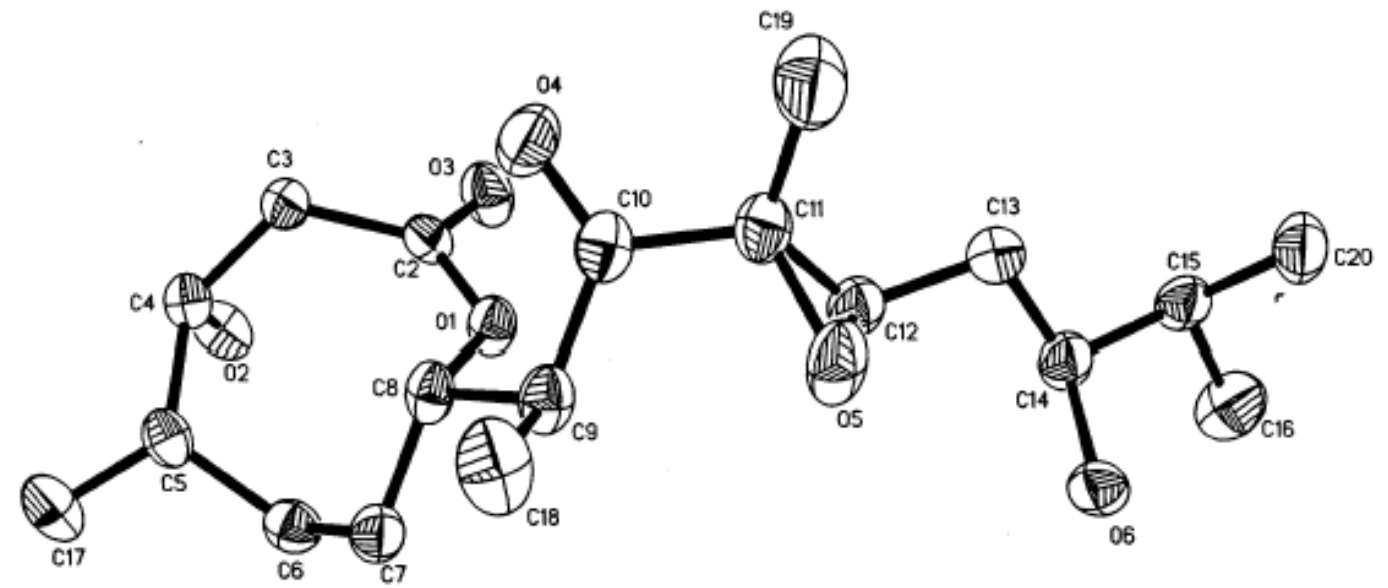

Figure 7. The X-ray crystal structure of synthetic octalactin A (1).

\section{References}

(1) Stott, K.; Stonehouse, J.; Keeler, J.; Hwang, T. L.; Shaka, A. J. J. Am. Chem. Soc. 1995, $117,4199-4200$.

(2) Still, W. C.; Kahn, M.; Mitra, A. J. Org. Chem. 1978, 43, 2923-2925.

(3) Perrin, D. D.; Amarego, W. L. F.; Perrin, D. R. Purification of Laboratory Chemicals; 2nd ed.; Pergamon: Oxford, 1980.

(4) Kruithof, K. J. H.; Schmitz, R. F.; Klumpp, G. W. Tetrahedron 1983, 39, 3073-3081.

(5) Ficini, J.; Normant, H. Bull. Soc. Chim. Fr. 1964, 1294-1298.

(6) Ullrich, F.-W.; Rotscheidt, K.; Breitmaier, E. Chem. Ber. 1986, 119, 1737-1744. 
(7) Paterson, I.; Goodman, J. M.; Isaka, M. Tetrahedron Lett. 1989, 30, 7121-7124.

(8) Ohtani, I.; Kusumi, T.; Kashman, Y.; Kakisawa, H. J. Am. Chem. Soc. 1991, 113, 40924096.

(9) Mori, K.; Koseki, K. Tetrahedron 1988, 44, 6013-6020.

(10) Denmark, S. E.; Fujimori, S. Synlett 2001, 1024-1029.

(11) Tapiolas, D. M.; Roman, M.; Fenical, W.; Stout, T. J.; Clardy, J. J. Am. Chem. Soc. 1991, 113, 4682-4683. 